SDD $-41 / 5$

\title{
REACTOR REFUELING - INTERIM \\ DECAY STORAGE
}

REV . 11

$$
\begin{aligned}
& \text { OFFICIAL RELEASE } \\
& \text { BYWHIC } \\
& \text { DATE } 40 \\
& \text { Stan } 18980
\end{aligned}
$$

\section{Approved for Public Release;}

Further Dissemination Unlimited

8.D. Aardal 08/13/2010 


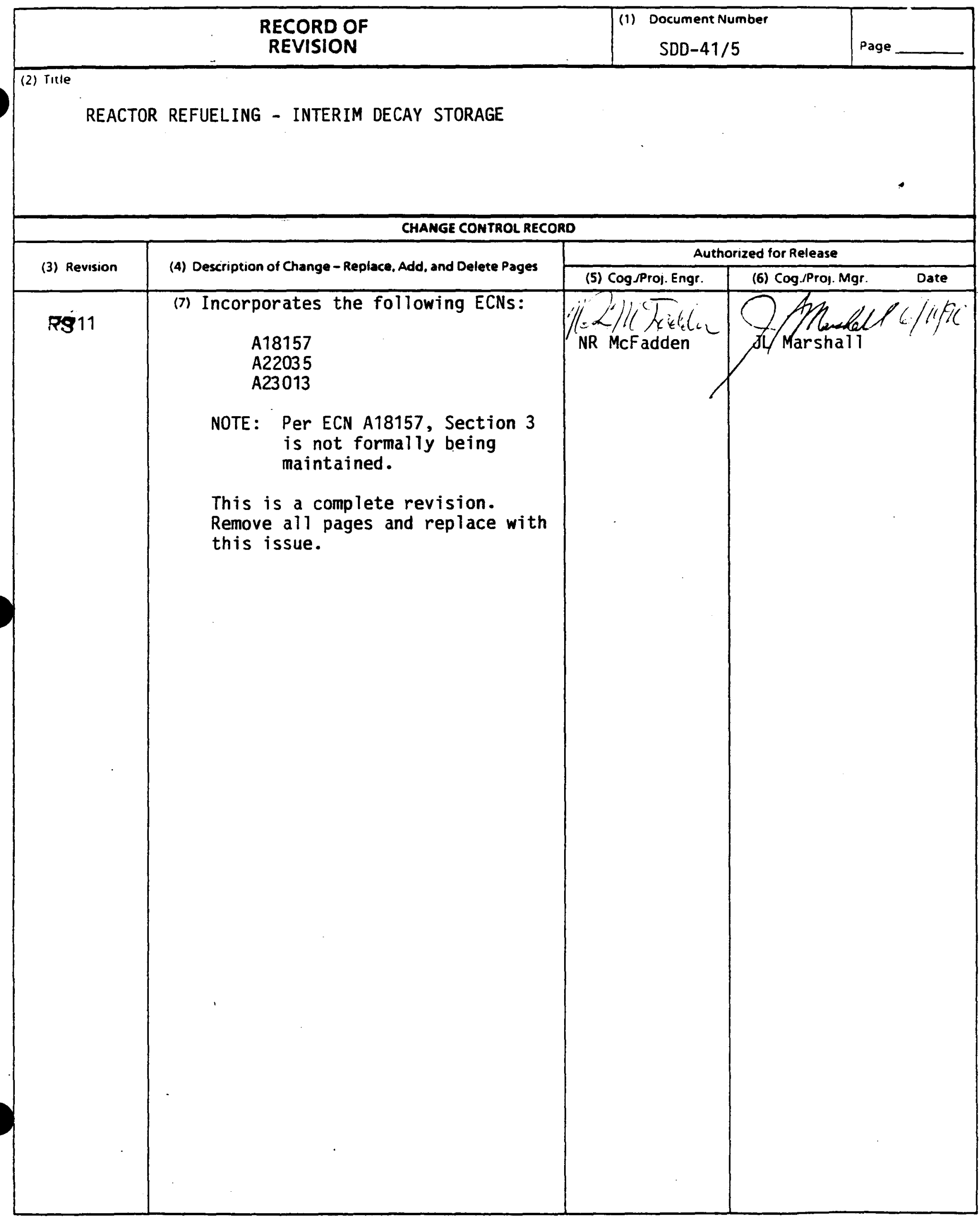

A.7320-005 (12/89) 


\section{CONTENTS}

1.0 Functions and Requirements .................. 1-1

1.1 Functions ..................... 1-1

1.2 Design Requirements ................... $1-1$

1.2.1 Environment ................... 1-1

1.2 .2 Process ...................... $1-4$

1.2.3 Mechanical .................. 1-15

1.2.4 Electrical ....................... $1-24$

1.2 .5 Thermal ................... $1-25$

1.2 .6 Safety .................. $1-26$

1.2 .7 Design Life .................... 1-28

1.2 .8 Maintenance .................... $1-28$

1.2.9 Instrumentation and Control ........... 1-30

1.2.10 Interface Requirements .............. 1-32

1.2.11 Quality Assurance ................ $1-40$

1.2.12 Codes and Standards ............... . 1-41

1.2.13 Safety Assurance ............... 1-43

2.0 Design Description ................... 2-1

2.1 Summary Description ................. . 2-1

2.2 Detailed Description ................. 2-5

2.2.1 Primary Vessel................ 2-5

2.2.2 Guard Tank................... . . . 2-6

2.2.3 Support Structure ............... 2-7

2.2.4 Top Shield.................. . 2-8

2.2.5 Omega Seal .................. 2-10

2.2.6 Storage Basket ............... 2-10

2.2.7 Ball Bearing ................. 2-12

2.2.8 Drive Train ................. 2-13

2.2.9 Thermal Shield................ 2-14

2.2.10 Bearing Support ................ 2-15

2.2.11 Storage Basket Index .............. 2-16

2.2.12 Control Cabinet ............... 2-17

2.2.13 Floor Valve Adapter .. . . . . . . . . . 2-18

2.2.14 Electrical and Instrumentation .......... 2-19

2.2.15 Impact Absorber .. . . . . . . . . . . . . 2-22

2.2.16 Argon Tubing and Manifold ........... . 2-23

2.2.17 Neutron Absorber .. . . . . . . . . . . . 2-23

2.2.18 Miscellaneous Parts and Special Tools . . . . . . 2-25

2.2.19 Interlocks................... 2-26

3.0 System Limitation, Casualty Events, and Response to
Casualty Events.......... . . . . . . . . . . . . . .

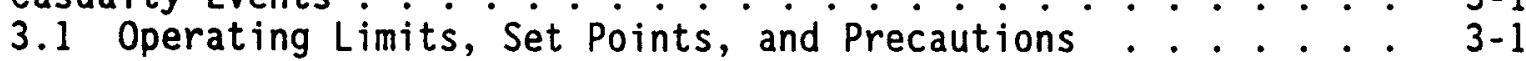

3.1.1 Operating Limits and Set Points .......... 3-1

3.1.2 Precautions .................. 3-2

3.2 Casualty Events .................. . . . . . $3-2$ 


\section{CONTENTS (continued)}

3.3 Design Features to Mitigate the Effects of a

Casualty Event ....................... 3-3

3.3.1 Loss of Primary Cooling ............... 3-3

3.3.2 Loss of Electrical Power ............. 3-3

3.3.3 System Leakage .................. 3-3

3.3.4 Dropped Load on the IDS Cover ............. . . $3-4$

3.3.5 Dropped Core Component During Transfer . . . . . . . 3-4

3.3.6 Dropped Test Assembly During Transfer ....... 3-5

3.3.7 Stuck Core Component During Transfer . . . . . . . 3-5

3.3.8 Loss of Cover Gas ............... . . . 3-6

3.3.9 Earthquake .................... $3-6$

3.3.10 Sodium Reaction ................. . . . . $3-6$

3.3.11 Cel1 Overpressure ................ . . . 3-7

3.3.12 Vessel Overpressure ............... . 3-7

3.4 Recovery Procedures . . . . . . . . . . . . . . . . . $3-7$

3.4.1 Loss of Primary Cooling . . . . . . . . . . . . 3-7

3.4.2 Loss of Electrical Power . . . . . . . . . . . . . . . . $3-7$

3.4.3 System Leakage ................. . . 3-8

3.4.4 Dropped Load on IDS Cover . . . . . . . . . . . . . . . . $3-8$

3.4.5 Dropped Core Component During Transfer . . . . . . 3-8

3.4.6 Dropped Test Assembly During Transfer ....... . 3-9

3.4.7 Stuck Core Component During Transfer . . . . . . . 3-9

3.4.8 Loss of Cover Gas . . . . . . . . . . . . . 3-9

3.4.9 Earthquake ................. . $3-10$

3.4.10 Sodium Reaction ............... . . $3-10$

3.4.11 Deleted. . . . . . . . . . . . . . . . 3-10

3.4.12 Cell Overpressure . . . . . . . . . . . . . 3-11

3.4.13 Vessel Overpressure . . . . . . . . . . . . . . $3-11$

3.4.14 Sodium Piping Leakage ................ . . . . . . .

\section{Appendixes:}

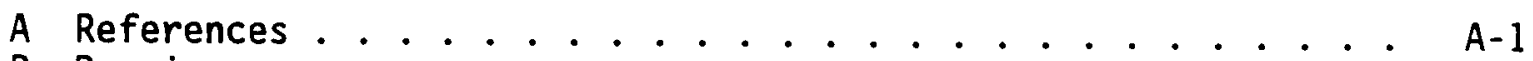

B Drawings ......................... . . . . .

C Data Sheets . . . . . . . . . . . . . . . $C^{-1}$ 


\section{LIST OF TABLES}

I Gamma Source From Irradiated Fuel . . . . . . . . . . . . . 1-3

II Stored Fuel Component Input . . . . . . . . . . . . . . . . 1-5

II A Argon Distribution System . . . . . . . . . . . . . . . 2-24

\section{LIST OF FIGURES}

I Primary Sodium Cooling . . . . . . . . . . . . . . . . 1-6

I Backup Nitrogen Cooling Operating Parameters . . . . . . . . . . 1-7

II Deleted ... . . . . . . . . . . . . . . . . . . . . . 1-8

IV Interim Decay Storage Cooling Arrangements . . . . . . . . . . . 1-9

V Interim Decay Storage $155 \mathrm{~kW}$ Calculated Transient Temperatures Seven Days Following Loss of Cooling Nominal Sodium Level . . . . 1-13

VI Interim Decay Storage $155 \mathrm{~kW}$ (140) Equilibrium Calculated Temperatures Cooling Loss Sodium Siphoned to 537 Elevation $(+2.2 \mathrm{ft}$ ) (Taken from Reference G)............. . 1-14

VII Interim Decay Storage Assembly .. . . . . . . . . . . . . . . 2-4 


\subsection{FUNCTIONS AND REQUIREMENTS}

\subsection{FUNCTIONS}

The functions of the Interim Decay Storage (IDS) are:

A. To provide a passive, controlled environment for temporary storage, without damage, of new components enroute to the reactor, and for irradiated core components and test assemblies removed from the reactor.

B. To supply sodium to fill new Core Component Pots.

c. To introduce new core components to sodium.

\subsection{DESIGN REQUIREMENTS}

\subsubsection{Environment}

A. The controlled environment (liquid sodium with argon cover gas) shall be maintained at values that do not compromise either the reactor performance characteristics of new components and assemblies or the condition (test data) of irradiated components and assemblies.

B. The sodium will have a working range from 350 to $500{ }^{\circ} \mathrm{F}$. Temperatures to $700^{\circ} \mathrm{F}$ will be permitted on an operating upset* basis. Temperatures to $1290^{\circ} \mathrm{F}$ at the vessel wall will be permitted on a faulted basis. Normal operating temperature is $400^{\circ} \mathrm{F}$.

*ASME Code Section III definition Section NB-3113. 
permitted on a faulted basis. Normal operating temperature is $400^{\circ} \mathrm{F}$.

C. The physical properties of sodium upon which this design is based shal1 be as reported in HEDL-TME 71-32.

D. Purity of sodium will be maintained by System 81 and $93-10$ as given in Paragraph $1.2 .10 \mathrm{~L}$.

E. Nitrogen gas shall be circulated through the cell for cooling and to maintain an inert atmosphere (see Section 1.2.10 H).

F. Source Activities and Gamma Spectra--The gamma $(\gamma)$ ray power of the radioactive components stored in the IDS is shown in Table I. The $\boldsymbol{\gamma}$-ray spectrum is arranged into $\boldsymbol{\gamma}$-ray energy groups. The total decay power is $223 \mathrm{~kW}$. Approximately $50 \%$ of this power will be in the form of beta particles and will be absorbed within the fuel. The remaining $50 \%$ will be in the form of $\gamma$ radiation.

The source activity values shall be based on all of the assemblies operating for one year and then allowed to decay for $90 \mathrm{~d}$. The IDS is limited to a decay heat of $155 \mathrm{~kW}$.

Due to spontaneous fissioning and the $(\alpha n)$ reaction with oxygen, each fuel assembly will emit a total of $1.0 \times 10^{8} \mathrm{n} / \mathrm{s}$ with an average energy of $3.0 \mathrm{MeV}$. 
Table I. Gamma Source From

Irradiated Fuel (one $5.33 \mathrm{MW}$ goal

exposure* element, 90 day decay).

\begin{tabular}{lr}
\hline Energy, MeV & Source, Photons/s \\
\hline $0-0.2$ & $1.6+15$ \\
$0.2-0.3$ & $9.9+13$ \\
$0.3-0.4$ & $3.6+13$ \\
$0.4-0.55$ & $4.1+15$ \\
$0.55-0.75$ & $3.8+15$ \\
$0.75-0.9$ & $9.4+15$ \\
$0.9-1.1$ & $1.1+13$ \\
$1.1-1.35$ & $3.6+13$ \\
$1.35-1.6$ & $1.7+14$ \\
$1.6-1.8$ & $2.0+12$ \\
$1.8-2.0$ & $6.7+11$ \\
$2.0-2.2$ & $3.5+13$ \\
$2.2-2.4$ & $4.6+12$ \\
$2.4-2.6$ & $3.8+12$ \\
$2.6-2.8$ & $1.1+14$ \\
$2.8-\infty$ & $1.4+11$ \\
\hline
\end{tabular}

The maximum specific activity of the sodium in the IDS will be as follows:

$$
\begin{aligned}
& { }^{24} \mathrm{Na}=5.8 \times 10^{-6} \mathrm{CI} / \mathrm{CC}^{\star \star} \\
& { }^{22} \mathrm{Na}=0.74 \times 10^{-6} \mathrm{Ci} / \mathrm{CC}^{\star \star \star}
\end{aligned}
$$

The cover gas activity will be no greater than $500 \mathrm{Cj}$ of $133 \mathrm{Xe}$. This is based upon the noble gas release from fuel pins and the decay time is greater than 15 days.

*Goal exposure is three operating cycles.

**This activity will occur after the fourth fuel transfer. The volume of primary sodium transferred to the IDS per fuel transfer is $3.6 \mathrm{ft}^{3}$. The reactor will be down for 2 day prior to the first fuel transfer. Elapsed time between transfers will be $6 \mathrm{~h}$.

$* * *$ This equals the value of ${ }^{22} \mathrm{Na}$ specific activity in the primary sodium. 
SDD-41/5, Rev. 11

\subsubsection{Process}

A. The operating and transfer cycle will be the following:

$\begin{array}{lc}\text { Reactor operation } & 102 \text { days } \\ \text { Reactor shutdown and core } & 28 \text { days } \\ \text { components transfer time } & 70 \text { days } \\ \text { Normal storage time in IDS* } & \\ \text { Elements handled per cycle: } & 22-24 \\ \text { Driver Fuel } & 3-6 \\ \text { Control/Safety Rods } & 12 \\ \text { Reflectors } & 2 \\ \text { Closed Loops (CLIRAs) } & 2-3 \\ \text { Open Test Assemblies (OTAs) } & \end{array}$

B. During the normal operation of the primary cooling system, sodium will be continuously circulated through the IDS vessel. Heat will be removed by this cooling system, or, when needed, heat will be added by the IDS preheat system as required to maintain the temperatures indicated on Figure I. See Figure IV for cooling arrangements.

C. Refer to Table II and Figures I and II for heat loads, temperatures and flow parameters.

*5.33 MW goal exposure assembly held in IVS for 130 days prior to storage in IDS. 
Table II. Stored Component Input.

\begin{tabular}{|c|c|c|c|c|}
\hline Items & Quantity & $\begin{array}{l}\text { Days } \\
\text { irradiated }\end{array}$ & $\begin{array}{l}\text { Days } \\
\text { decay }\end{array}$ & Decay heat \\
\hline \multicolumn{5}{|c|}{ Normal (typical refueling) } \\
\hline \multirow{4}{*}{$\begin{array}{l}\text { Drivers - new } \\
12 \mathrm{ft} \text { test assemblies } \\
\text { Drivers - spent } \\
\text { Irradiated } 12 \mathrm{ft} \text { test } \\
\text { assemblies } \\
\text { Open test assembly - } \\
\text { fueled } \\
\text { Closed loop }\end{array}$} & $\begin{array}{l}15 \\
10 \\
15 \\
10\end{array}$ & $\begin{array}{r}0 \\
0 \\
306 \\
306\end{array}$ & $\begin{array}{r}0 \\
0 \\
155 \\
25\end{array}$ & $\begin{array}{c}0 \\
0 \\
28.5 \\
60.0\end{array}$ \\
\hline & 2 & 306 & 155 & 3.8 \\
\hline & 1 & 306 & 25 & 2.2 \\
\hline & & \multicolumn{2}{|c|}{$\begin{array}{l}\text { Total } \\
\text { with contingency }\end{array}$} & $\begin{array}{r}94.5 \\
100.0\end{array}$ \\
\hline \multicolumn{5}{|c|}{$\begin{array}{c}\text { Maximum (reactor unloaded- } \\
210 \mathrm{~d})\end{array}$} \\
\hline \multirow{2}{*}{$\begin{array}{l}\text { Drivers - spent } \\
(5.33 \mathrm{MW}) \\
12 \mathrm{ft} \text { test assemblies } \\
(5.33 \mathrm{MW})\end{array}$} & $\begin{array}{l}15 \\
15 \\
15\end{array}$ & $\begin{array}{l}306 \\
204 \\
102\end{array}$ & $\begin{array}{l}210 \\
210 \\
210\end{array}$ & $\begin{array}{l}21.0 \\
17.0\end{array}$ \\
\hline & $\begin{array}{l}10 \\
10 \\
10 \\
10\end{array}$ & $\begin{array}{l}102 \\
306 \\
204 \\
102\end{array}$ & $\begin{array}{l}210 \\
210 \\
210 \\
210\end{array}$ & $\begin{array}{r}11.0 \\
14.0 \\
11.0 \\
7.5\end{array}$ \\
\hline $\begin{array}{l}\text { Open test assemblies } \\
(5.33 \mathrm{MW} \times 150 \%)\end{array}$ & $\begin{array}{l}2 \\
2 \\
2 \\
2\end{array}$ & $\begin{array}{l}306 \\
204 \\
102 \\
306\end{array}$ & $\begin{array}{l}210 \\
210 \\
210 \\
340\end{array}$ & $\begin{array}{l}4.0 \\
3.3 \\
2.2 \\
2.2\end{array}$ \\
\hline \multirow[t]{2}{*}{$\begin{array}{l}\text { Closed loops } \\
(2.0 \mathrm{MW})\end{array}$} & $\begin{array}{l}1 \\
1 \\
1\end{array}$ & $\begin{array}{l}306 \\
204 \\
102\end{array}$ & $\begin{array}{l}210 \\
210 \\
210\end{array}$ & $\begin{array}{l}1.0 \\
0.8 \\
0.5 \\
\end{array}$ \\
\hline & & \multicolumn{2}{|c|}{$\begin{array}{l}\text { Total } \\
\text { with contingency }\end{array}$} & $\begin{array}{r}95.5 \\
100.0\end{array}$ \\
\hline \multicolumn{5}{|l|}{ Single components } \\
\hline \multicolumn{4}{|c|}{$\begin{array}{l}\text { Peak decay power, single core component } \\
\text { Peak decay power, single closed loop (CLIRA) } \\
\text { Peak decay power, single open test assembly }\end{array}$} & $\begin{aligned} 10.0 \mathrm{~kW} \\
2.4 \mathrm{~kW} \\
4.0 \mathrm{~kW}\end{aligned}$ \\
\hline
\end{tabular}




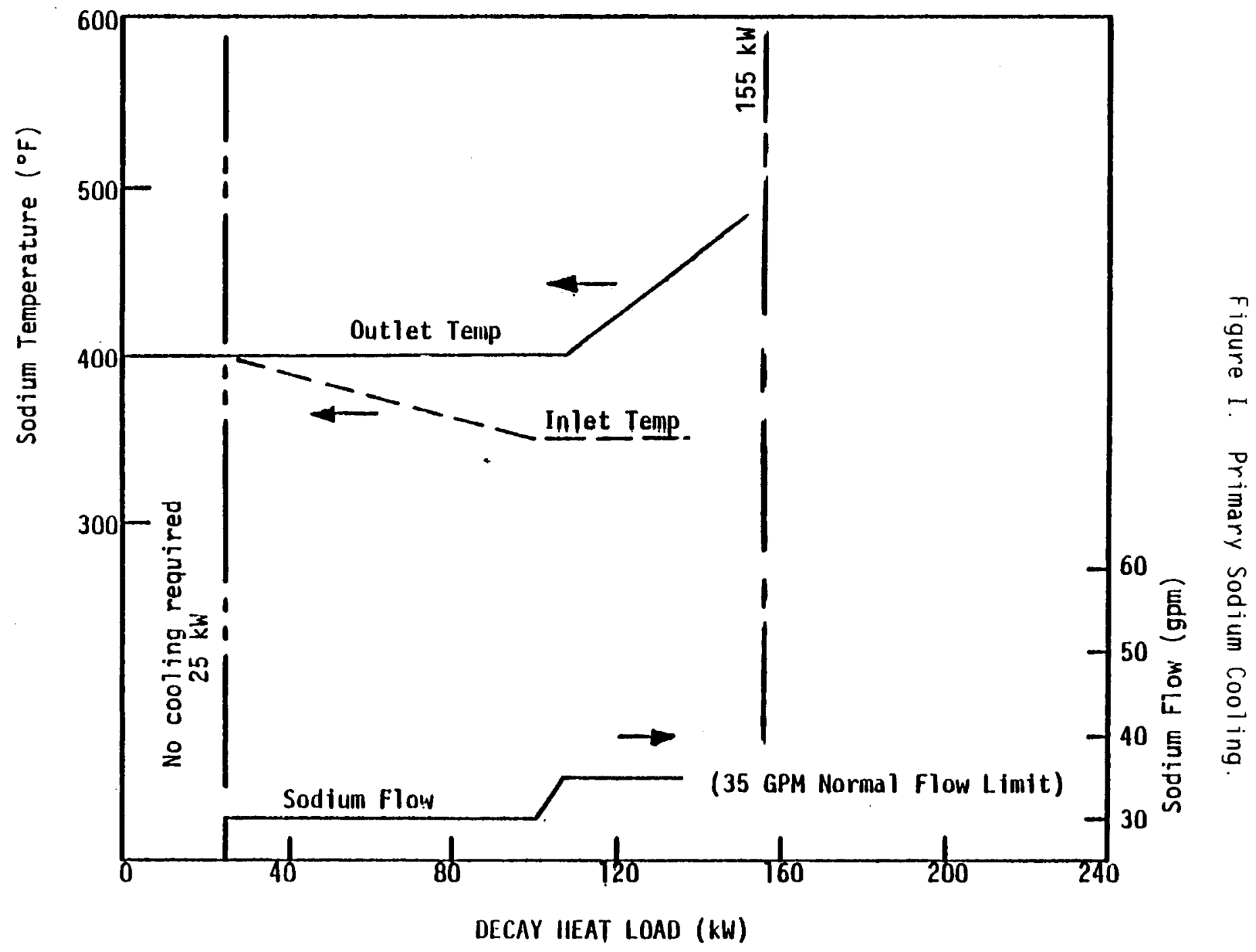

NOTES: (1) The IDS decay heat inventory is limited to $155 \mathrm{~kW}$.

(2) IDS normal operating temperature is $400^{\circ} \mathrm{F}$. Outlet temperature will increase but remain below $500^{\circ} \mathrm{F}$ at decay heat loads between 110 and $155 \mathrm{~kW}$. 


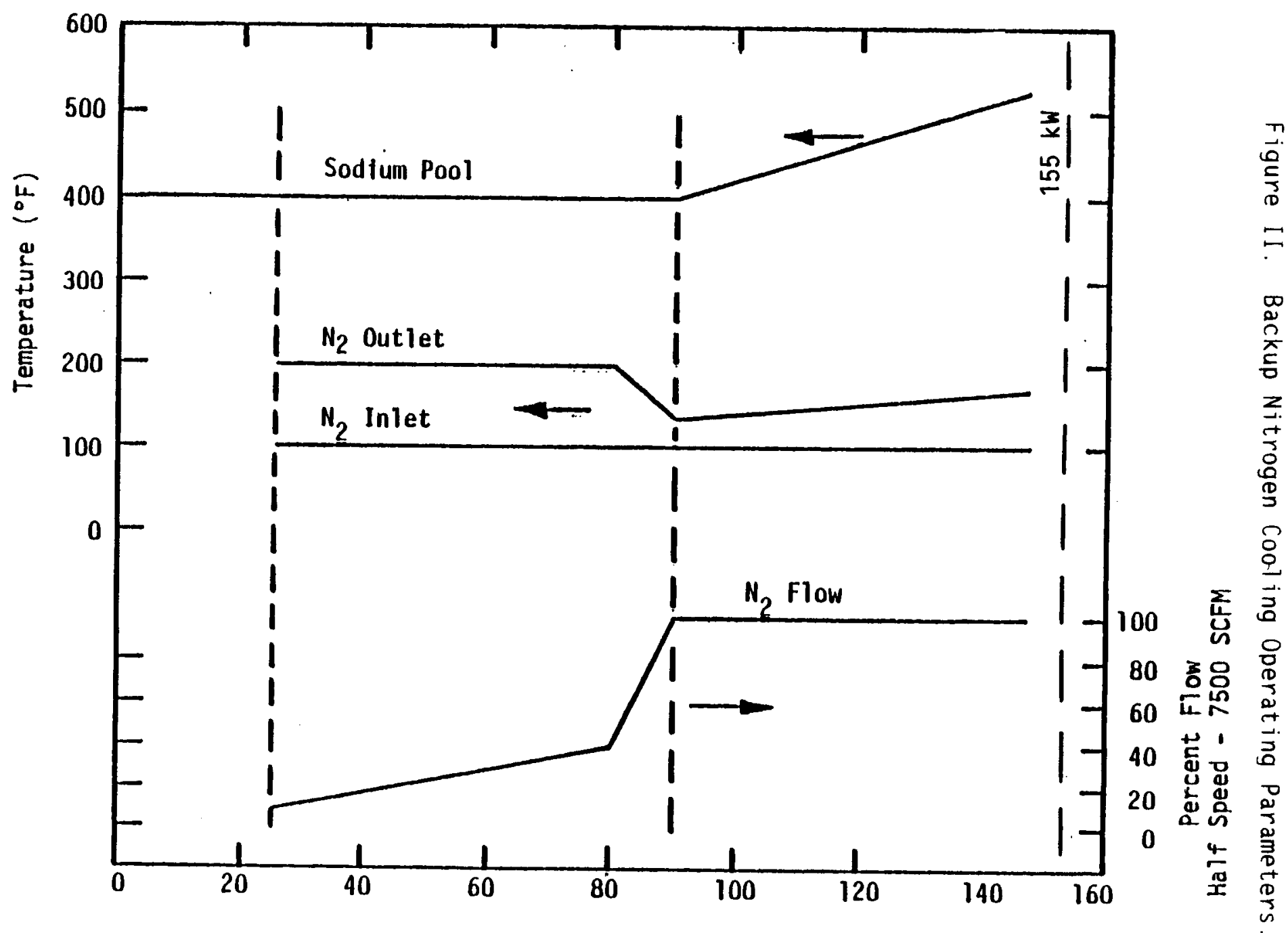

NOTES: (1) At cooling loads below $90 \mathrm{~kW}$, the $N_{2}$ system operates with partial bypass flow.

(2) Full speed fan operation is not required below $155 \mathrm{~kW}$.

(3) The IDS decay heat inventory is i imited to $155 \mathrm{~kW}$.

(4) IDS normal operating temperature is $400^{\circ} \mathrm{F}$. 
SDD-41/5, Rev. 11

6-29-90

Figure III. Interim Decay Storage Cooling Flow Parameters Emergency Conditions.

THIS FIGURE WAS DELETED 
Figure IV. Interim Decay Storage Cooling Arrangements

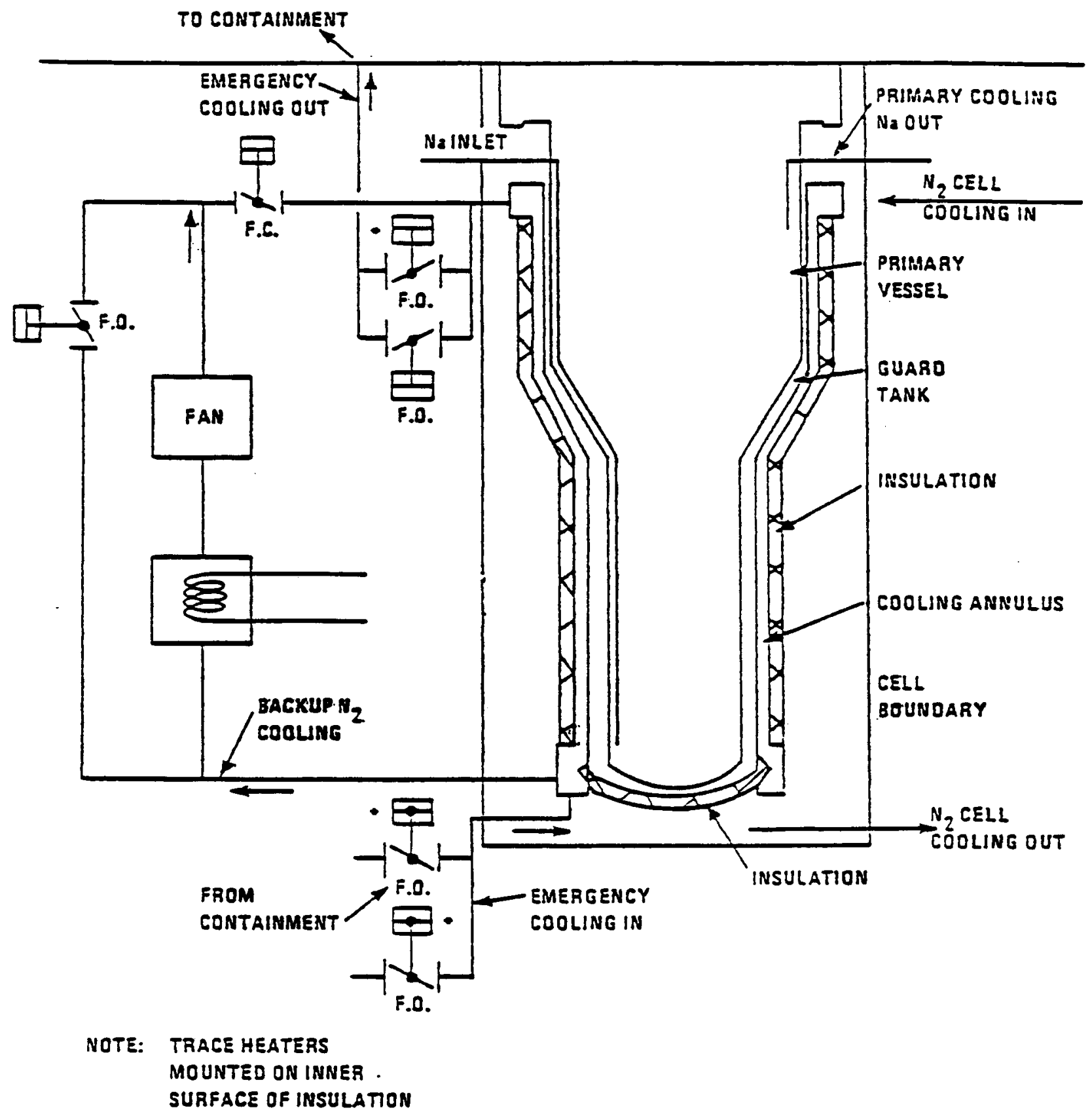

* Valves may be activated by manual operation if Containment is accessible. 
D. The sodium level in the IDS will be maintained above the top of the core component pots. Sodium will be continuously circulated through the vesse?.

E. Preheat--The IDS preheating system shall be capable of heating the guard tank, primary vessel, and internals, without sodium in the vesse1, from ambient temperature to $400^{\circ} \mathrm{F}$ within $100 \mathrm{~h}$, at a nominal rate of $4^{\circ} \mathrm{F} / \mathrm{h}$.

The heat-up rate without sodium shall not exceed. $10^{\circ} \mathrm{F} / \mathrm{h}$.

The heat-up rate with sodium in the vessel shall not exceed $50^{\circ} \mathrm{F} / \mathrm{h}$.

F. Operating Conditions.

Normal Conditions--The IDS shall meet the normal operating conditions specified in Table II and Figures I and II.

Upset Conditions--Local thermal transients on the IDS inlet nozzles from System 81 will be as follows:

1. A temperature reduction of $5^{\circ} \mathrm{F} / \mathrm{sec}$ over a $25 \mathrm{sec}$ time period which may occur twice in the life of the plant.

2. A temperature reduction of $2^{\circ} \mathrm{F} / \mathrm{sec}$ over a $100 \mathrm{sec}$ time period which may occur once per year for $20 \mathrm{yr}$.

Loss of primary sodium cooling when the reactor is completely unloaded (see Figure II).

Emergency Conditions.

1. Dropped Core Component, Core Component Pot or Test Assembly-The IDS shall withstand, without damage to stored components, 
the effect of impact loads due to dropping of a core component or a test assembly from CLEM or BLTC at maximum height. The component may drop in a stored position or on the closed floor valve, hence floor valve adapter and top shield. The basis for establishing the total load shall include the combined free fall of the grapple, pot, sodium and component from the maximum height obtainable in the CLEM or BLTC, which is $10 \mathrm{ft}$ above the top shield.

A core component pot, with core component, sodium and grapple, at a weight of 2,265 1b, or a test assembly, with grapple, at a weight of $2,5801 \mathrm{~b}$, may fall from $10 \mathrm{ft}$ above the top shield onto a closed floor valve.

2. Dropped Floor Valve--The floor valve adapter and the top shield shall withstand the impact from a dropped floor valve from 24 inches, with an edge impact. An edge is defined as the intersecting line of any two major adjacent plate surfaces upon which the floor valve could fall. Impact forces shall be considered to be evenly distributed along the edge and vertically oriented.

3. Dropped Maintenance Cask--Damage to the IDS shall meet the above limitations on damage when a maintenance cask is dropped from 33 inches onto one side of the railroad car in such a manner that the major load is taken by four wheels of a truck located on the impact absorber. The lateral loads developed shall be considered to be $10 \%$ of the vertical loads.

4. Vault Overpressure--The IDS must be capable of surviving a sodium spill inside vault 546 and the potential overpressure of the cell atmosphere to 12 psig. The IDS shall be considered to be at $500{ }^{\circ} \mathrm{F}$ and 6 inch $\mathrm{H}_{2} \mathrm{O}$ gage pressure at this occurrence. The vessel, its contained sodium, the omega seal 
and the piping attached to the vessel shall remain intact during and after the overpressure.

Faulted Conditions--Four events can be postulated that could impair the integrity and operability of the IDS. Each of these events shall be considered as independent events. The mechanical integrity of the IDS shall

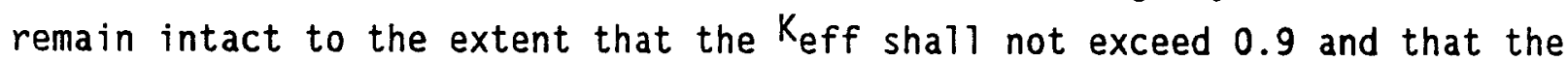
sodium and gas pressure boundaries remain intact. Plastic deformation of metallic components is acceptable providing the pressure boundary remains intact. Elastomeric seals will be permitted to degrade as a result of high temperatures. Post accident operability of IDS is not required. After the event, the IDS shall be inspected and requalified prior to reuse.

1. Loss of Power--The IDS must survive a loss of power and the subsequent loss of all cooling for a period up to $7 \mathrm{~d}$ and with up to $155 \mathrm{~kW}$ at the start of the power outage. The temperatures in the IDS during these conditions are shown in Figure $V$.

2. Sodium Spi11--The IDS must survive a loss of cooling resulting from a sodium spill into cell 546. The temperatures resulting from this condition are shown in Figure VI.

3. Design Basis Earthquake--The IDS shall meet the design criteria listed in JABE-WADCO-02, Category I. The appropriate response curves for the detailed analysis are presented in HWS 1386, Rev. 7. 
SDD-41/5, Rev. 11 $6-29-90$

Figure $V$. Interim Decay Storage

155 kW Calculated Transient Temperatures Seven Days

Following Loss of Cooling Nominal Sodium Level

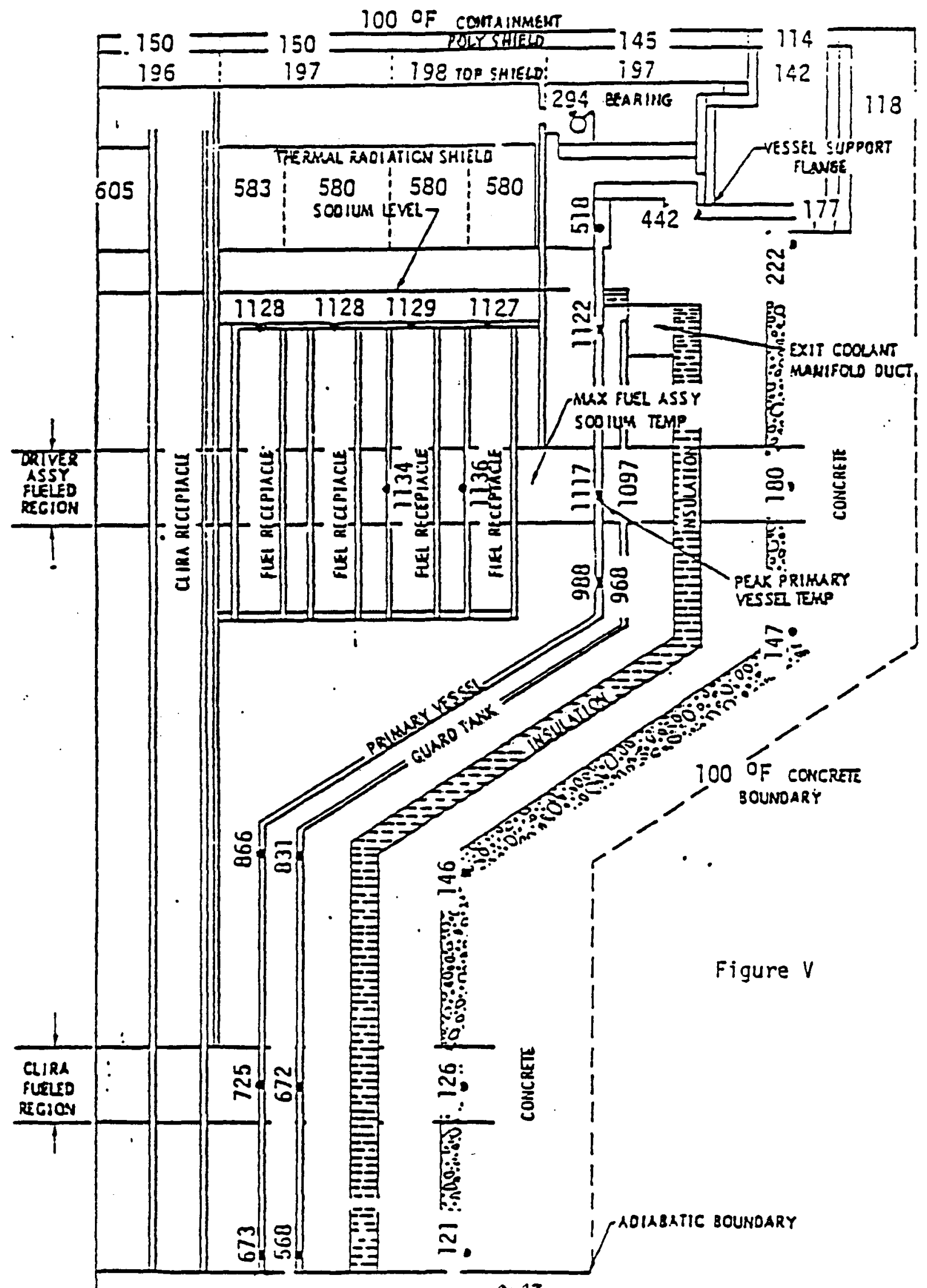

$-13$ 
Figure VI. Interim Decay Storage

155kW (140) Equilibrium Calculated Temperatures Cooling Loss Sodium Siphoned to 537 Elevation $(+2.2 \mathrm{ft}$ ) (Taken from Reference $\mathrm{G}$ )

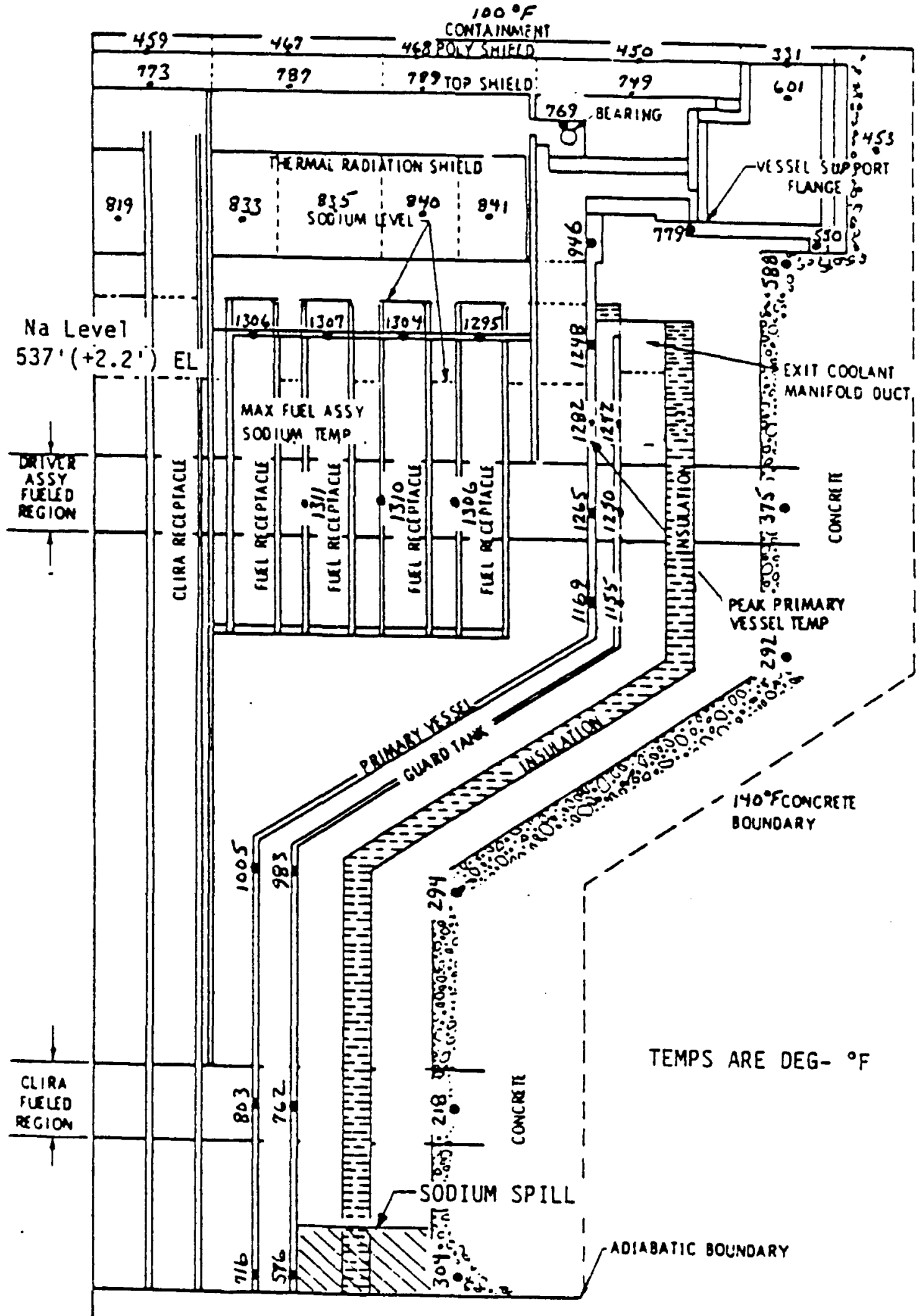


4. Stuck Fuel--The IDS top shield shall permit a Core Component Pot, containing a driver fuel assembly and generating $10 \mathrm{~kW}$ of decay heat to be immobilized in a top shield transfer port for an indefinite period of time.

G. The sodium in the primary vessel will be circulated through Systems 81 and 85 for cold trapping and monitoring for sodium impurities.

\subsubsection{Mechanical}

A. Drawings--Drawings of the IDS are shown in Appendix B.

B. Major Components List--The IDS consists of the following major components:

1. Primary vessel

2. Guard tank

3. Support structure

4. Top shield

5. Omega seal

6. Storage basket

7. Ball bearing

8. Drive train

9. Thermal shield

10. Bearing support

11. Storage basket indexer

12. Control cabinet

13. Floor valve adapter

14. Electrical and instrumentation systems

15. Impact absorber

16. Argon tubing and manifold

17. Neutron absorber 
18. Miscellaneous parts and special tools

19. Interlocks

20. Visual indexer.

C. Location of IDS Installation--The IDS will be located in Cell No. 546 in the reactor containment building, with the top of the impact absorber at containment floor level (550 ft 0 inch).

It will be within the rails for the CLEM transporter, such that all ports are accessible to CLEM.

The rails for the BLTC transporter will extend over the top of the IDS, so that all transfer ports are accessible to the BLTC.

The IDS shall be within the reach of the building crane hook.

D. Primary Vessei--The primary vessel will be designed and built to ASME Section III Class I and shall contain the sodium coolant and confine (in conjunction with other members) radioactive contaminants within the primary system.

The support structure shall support the primary vessel. A bottom guide will transfer lateral loads to the base structure.

The minimum envelope diameter of the vessel is set by the rotating storage basket diameter; the length is set by the closed loop storage tubes.

All nozzles shall be located as high as feasible, considering all process and mechanical requirements. Nozzles shall be provided for the primary sodium circuit, sodium drain, and argon services. All lines will be 2 inches diameter. 
Primary Vessel Temperatures and Pressure

\begin{tabular}{|c|c|c|c|c|c|}
\hline \multirow{2}{*}{$\begin{array}{l}\text { Reference } \\
\text { Temp. }\end{array}$} & \multirow{2}{*}{$\begin{array}{l}\text { Design } \\
\text { Press. }\end{array}$} & \multicolumn{2}{|c|}{ Inerting } & \multicolumn{2}{|c|}{ Draining } \\
\hline & & Temp. & Press. & Temp. & Press. \\
\hline $700^{\circ} \mathrm{F}$ & $\begin{array}{l}4 \text { psig } \\
\text { plus static } \\
\text { head of } \mathrm{Na}\end{array}$ & $70^{\circ} \mathrm{F}$ & $29 \mathrm{in.} \mathrm{Hg}$ & $400^{\circ} \mathrm{F}$ & 3 psig \\
\hline $600^{\circ} \mathrm{F}$ & $\begin{array}{l}10 \text { psig } \\
\text { external }\end{array}$ & & & & \\
\hline
\end{tabular}

E. Guard Tank--The guard tank will be designed and built to ASME Section VIII, Division 1. It will be supported at the upper cone joint with the upper cylinder. Lateral support will be provided at the bottom.

The guard tank shall maintain the sodium level in the primary vessel above the fueled portion of the core components in the event of a leak in the primary vessel.

The top of the guard tank shall be approximately $1 \mathrm{ft}$ below the primary vessel nozzles to avoid interference.

The guard tank shall be designed for the following conditions:

Guard Tank Temperatures and Pressures

\begin{tabular}{lllll}
\hline & Reference & Design & \multicolumn{2}{c}{ Inerting } \\
Temp. & Press. & Temp. & Press. \\
\hline Guard Tank & $700^{\circ} \mathrm{F}$ & $\begin{array}{l}\text { Ambient plus } \\
\text { Static Head of Na }\end{array}$ & $70^{\circ} \mathrm{F}$ & Ambient \\
\hline
\end{tabular}


F. Top Shield and Thermal Barrier--The primary functions of the top shield are to:

1. Attenuate the neutrons and gamma radiation from the stored assemblies, from the sodium, and the assemblies being transferred

2. Thermally insulate the working area from the storage volume

3. Provide controlled access to the storage basket

4. Seal the storage volume from the working area

5. Support the impact absorber structure and protect the storage area from dropped loads (as part of the impact absorber structure)

6. Support the BLTC raits

7. Support the interfacing fuel handling equipment.

The IDS top shield shall maintain radiation levels at the operating deck within the limits specified. in 1.2.6.I.

Temperature and liquid level instrument sensors shall be mounted in service ports in the top shield, and shall extend down into the vessel and sodium pool.

Normal access to the IDS storage is through the five transfer ports, located midway between the Bottom Loading Transfer Cask (BLTC) tracks. 
The top shield shall be designed for the following conditions:

Top Shield Temperatures and Pressures

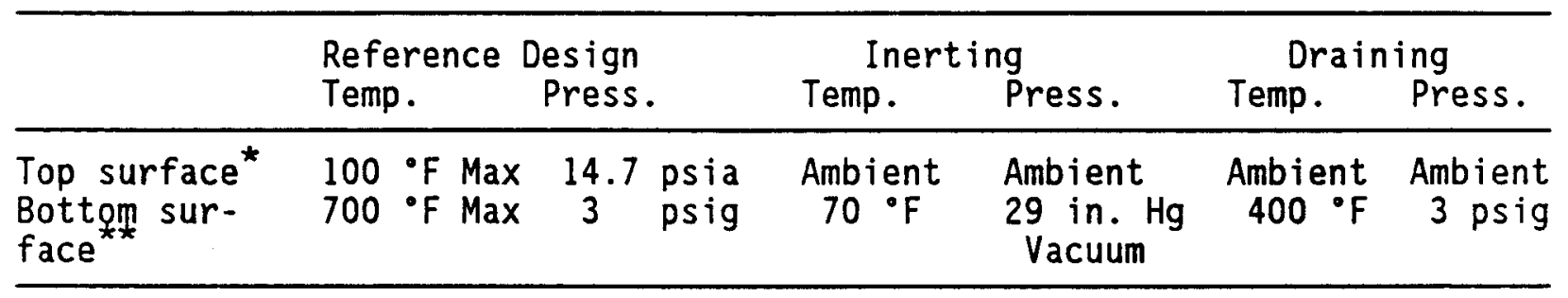

G. Support Structure--The weight of the top shield, the primary vessel and its contents, the rotatable basket, and the stored components plus applied external forces will be supported by a support structure. The support structure must be able to withstand a 10 psig vault pressure due to a sodium spil1.

H. Impact Absorber--The function of the impact absorber is to protect the IDS functional capability against accidentally dropped external loads.

The impact absorber shall prevent or reduce the damage to the IDS internals as a result of the following defined dropped loads:

1. A drop of the floor valve (weight 8.5 tons) from 24 inch maximum height with an edge impact.

2. A drop of the segmented maintenance cask (weight 142 tons) from 33 inch maximum onto one side of the railroad car such that the major load is taken by the wheels of the truck located over the IDS cover. Lateral as well as vertical loads may develop from such an impact. For a description of the railway car, refer to the interface section.

\footnotetext{
*550 ft Leve?.

**Bottom surface of the Thermal Shield.
} 
Design criteria are:

1. The impact absorber be repairable or replaceable

2. That the internals (basket) and drives remain operable

3. The guard tank and primary vessel and nozzles remain intact

4. The top shield and plugs remain undamaged.

I. Rotatable Storage Basket--The primary function of the rotatable storage basket is:

1. To provide orderly transient storage for radioactive core components in an array with a subcritical multiplication, which is consistent with safety and neutron stielding requirements.

2. To minimize the number of fuel ports and multiple fuel handling operations.

The storage basket shall provide storage capacity for $1-1 / 3$ core loadings, or 112 core components and 10 test assemblies.

The rotatable storage basket shall have the capability for aligning of each storage basket location with its access port.

Positive location identification means shall be employed for storage and retrieval purposes.

Core components shall be stored in core component storage pots. The pots shall be stored in a vertical attitude.

The storage basket and storage tubes shall withstand, without damage, the effects of impact loads due to the dropping, from the maximum height, of a core component pot with core component, or a test assembly, from CLEM into a storage tube. The basis for 
establishing the total load shall include the combined free fall of the grapple, pot, sodium, and component, maximum weight of $2,265 \mathrm{lb}$, from the height of $10 \mathrm{ft}$ above the floor elevation.

A test assembly with grapple (maximum weight of 2,580 lbs) may fall from a height of $10 \mathrm{ft}$ above the floor elevation.

The basket shall be capable of operating with off-center loads up to 56 fuel elements.

J. Drive System--Each position in the storage basket shall be indexable under its proper port by means of the basket rotational drives and controls.

Position selection and monitoring of operation shall be accomplished with the IDS Drive Train Assembly and Drive Control System.

Positioning at a given location shall be accomplished within plus or minus $1 / 4$ inch, relative to the true position.

Direct optical or mechanical means shall be provided for determining position of the rotatable storage basket.

The time required to reach any desired storage position, after the start switch is turned on, shall not exceed 10 minutes.

The drive shall be located in a cavity in the support structure.

K. Control System and Cabinet--Refer to Section 1.2.9, Instrumentation and Control. 
L. Preheaters--The requirements for the preheater assemblies are:

1. The heaters shall be sized and controlled to meet the requirements for preheating specified in Process

Section 1.2.2 E

2. The heaters shall be electrical-resistance type

3. The heaters are a component of the IDS Cell.

M. Omega Seal--The seal between the primary vessel and the support structure will prevent the radioactive gases and sodium vapor in the IDS cover gas from entering into the cell atmosphere.

The seal will be required to accommodate differential thermal expansions between the primary vessel flange and the support structure, including faulted conditions.

The seal shall be designed for a pressure differential equal to the maximum design and test pressure difference between the atmospheres in the IDS and the vault.

N. Floor Valve Adapter--The floor valve adapter will provide a positive seal between the floor valve and the IDS transfer ports.

0. Static Seals--All replaceable plugs and non-welded joints in the pressure boundary, to prevent the radioactive gases from escaping, shall be sealed with double elastomeric seals, with inert gas pressure connections to allow buffering of the space between the seals.

A-connection shall be provided for a gas line, valve, and gauge to allow monitoring or periodic verification of seal integrity. 
The seal gland design of the removable assemblies shall be selected such that the elastomeric seals shall remain on the plug during normal handling yet be readily removable for maintenance.

P. Materials of Construction - Material Selection--The materials of construction shall provide no contaminants transferable to the stored items.

The following components shall be fabricated of the materials specified:

1. Primary Vessel

2. Guard Tank

3. Tank Insulation

4. Rotatable Storage Basket

5. Support Structure

6. Impact Absorber

7. Floor Valve Adapter

8. Bearing and Gears

9. Omega Seal
Austenitic Stainless Steel (RDT M 5-1)

Carbon Steel (SA-516)

Calcium Silicate (ASTM C 533)

Austenitic Stainless Steel

(RDT M 5-1)

Carbon Stee] (RDT M 5-2)

Confinement Boundary only

(other SA-516)

Carbon Steel

Stainless Steel (SA-240

Type 304)

AFBMA and AGMA Standards

Austenitic Stainless Steel

(RDT M 5-1) 
10. Top Shield

11. Reflective

Insulation
Carbon Stee1 (ASME SA-516)

Stainless Steel (SA-240

Type 304) with ASTM A480

No. 4 Finish, both sides.

Q. Fabrication--Fabrication process requirements including surface finish, screw thread requirements, cleanliness, welding, assembly identification, and handling are specified in the ordering data for each component.

R. Handling--Packaging of all components except the bearing will be in accordance with RDT F 7-2T. Handling will be in accordance with RDT F 8-6T. All critical items will be designated.

Dynamic loadings shall be specified by the supplier. All major components shall be shipped with an accelerometer.

\subsubsection{Electrical}

A. Required electrical power includes single and three phase, unregulated 480, 277, and $120 \mathrm{Vac}$; single and three phase, regulated $120 \mathrm{Vac}$; and $125 \mathrm{Vdc}$.

B. Electrical interlocks shall be provided to prevent inadvertent operations during the interaction between the IDS and the following:

CLEM

BLTC

C. Electrical heaters shall be provided for preheating and shall conform to RDT P 4-3T. There shall be a $25 \%$ excess heater capacity 
to accommodate random heater failure during the plant lifetime, since heater replacement is not practical. The failure of one heater shall not result in unacceptable heating of the guard vessel and/or the primary vessel.

D. Electrical wiring will conform to the codes and standards referenced by SDD-12 Plant Electrical System.

\subsubsection{Thermal}

A. Thermal Performance--See Section 1.2.2, Process.

B. Temperature Limitations--For the operating modes shown on Figures I and II, the IDS, together with the associated process systems, shall meet the following temperature limitations:

1. The steady state temperature of the outside of irradiated test assembly center fuel pin cladding shall be maintained at $800^{\circ} \mathrm{F}$ or less; except, points irradiated above $800^{\circ} \mathrm{F}$ may exceed the irradiation temperatures by $50^{\circ} \mathrm{F}$ but in no case greater than $1000^{\circ} \mathrm{F}$. This temperature limitation applies during storage in IDS and during transfer of the test assembly in and out of IDS.

2. The maximum fuel pin clad temperature of irradiated heat producing core components to be processed without further examination shall be kept below $1200^{\circ} \mathrm{F}$ during storage in IDS and during transfer in and out of IDS.

3. The maximum fuel pin cladding temperature shall not exceed $1500^{\circ} \mathrm{F}$ during emergency conditions. 
4. The temperature of the IDS top surface at the $550 \mathrm{ft}$ level shall not exceed $100^{\circ} \mathrm{F}$.

5. The outside surface of the guard tank insulation shall not exceed $140^{\circ} \mathrm{F}$.

\subsubsection{Safety}

A. The IDS design, fabrication, and erection shall comply with all applicable federal, state and local regulations.

B. The IDS shall maintain the stored components in a subcritical condition ( $K_{e f f},<0.9$ ) under all normal and abnormal conditions.

C. Subsystems containing water or organic fluids in the vicinity of the IDS will have two barriers between them and the sodium.

D. No halogen or halogen-containing material shall be used in the IDS.

E. No neutron moderating materials which will adversely affect reactivity will be used within the IDS.

F. Use of cast iron, cast steel, bronze, and brazing in any lifting or handling fixture shall be prohibited.

G. Design shall prevent parts of IDS equipment from detaching and dropping into the IDS.

H. Hydrocarbon shall not be used in locations where there is a possibility of sodium contamination. 
I. Shielding--The equipment and handling procedures shall limit personnel radiation exposure levels to those specified in ERDA Manual Chapter 0524, Standards for Radiation Protection.

The maximum level of radiation above the top shield shall not exceed $0.2 \mathrm{mrem} / \mathrm{h}$ gamma-plus neutrons at the operating floor level.

Where penetrations through the radiation shield allow radiation beams into controlled access area, the average dose of each beam at the beam exit shall not exceed $20 \mathrm{mrem} / \mathrm{h}$ and the cross-section area of the beam shall not exceed $1 \mathrm{~cm}^{2}$ for normal conditions and $10 \mathrm{~cm}^{2}$ for recovery conditions.

During transfer operations, when core components or test assemblies are being transferred through the shield, the radiation level in accessible areas shall not exceed $2 \mathrm{mrem} / \mathrm{h}$.

NOTE: In determining compliance with this requirement, consideration shall be given to the shielding provided above the top shield by the floor valve and adapter, and CLEM, BLTC, or PHF.

For vapor trap and motor drive pits, the design radiation levels will be less than $200 \mathrm{mrem} / \mathrm{h}$. Infrequent access is required into these spaces.

J. Leakage of radioactive gases from the IDS containment shall be so limited that the concentration of radioactive gas from IDS in containment air will not prohibit normal access to the containment building. The vapor space above the sodium in IDS will contain argon.

The buffered seal arrangement provides an effective barrier to flow across the two seals and buffering zone. Any direct leakage to containment would be buffering gas. 


\subsubsection{Design Life}

A. The components shall have the following lifetimes and operating cycles:

1. Major components of the IDS such as the primary vesse1, guard tank, storage basket, storage basket drives, main bearing, support structure, top shield, and piping shall be designed for a 20 yr minimum service life.

2. Components other than the above for which a 20 yr design 1 ife is not economically justified shall be designed for a lesser lifetime and shall be repairable or replaceable. Greater than 5 yr will be a design goal.

3. The rotatable storage basket shall be capable of being positioned for loading or unloading of core components approximately 100 times during each reactor refueling period, of which there will be a maximum of 3 per yr. The components shall be capable of undergoing this duty cycle for the use-fuel life of the system. The requirements for unscheduled, complete loading (or unloading of the reactor core) are 5 cycles.

\subsubsection{Maintenance}

A. The IDS shall be designed for hands-on maintenance insofar as possible and for remote maintenance and replacement of irradiated or contaminated components when hands-on maintenance is not practical.

B. Maintenance shall be performed with the stored components in the IDS maintained under the normal environmental conditions as much as possible. 
C. All working parts subject to wear or requiring periodic replacement shall be accessible for replacement.

D. Elastomeric seals shall be readily accessible and replaceable.

E. Design of the equipment shall permit rapid removal and replacement of module units to the extent that is practical.

F. The designs shall include features to permit cleaning, removal of sodium and radioactive decontamination of external surfaces which become contaminated during handling operations.

G. Unusual maintenance, infrequently required, is to be considered in the design.

H. A manway into the vault shall be provided through the support structure for inspection of the primary vessel nozzles. This will be possible only when IDS is unloaded of sodium and fuel.

I. The IDS top shield shall be removable for maintenance.

J. When personnel access is required, maintenance procedures and design features will be specified.

L. For each component and subsystem, one of the following methods shall be selected to provide a basis for maintainability evaluation and analysis:

1. Adjustment in place

2. Replacement of a component by a spare (followed by repair and requalification of the component) 
3. Removal of components for decontamination and repair by contact maintenance followed by reinstallation of the same component

4. Repair of components in place using contact maintenance consistent with radiation exposure and other personnel safety considerations

5. Decontamination, either internal, external, or both, of components and cells to permit maintenance or for remote repair in a maintenance cell

6. Remote repair of components in place.

M. Instruments, tools, and other equipment necessary for initial installation and usual maintenance of the IDS and designed for use on the IDS shall be classified as special tools and shall be considered as part of the IDS.

N. Provisions shall be made to prevent sodium transport into compartments requiring access for maintenance.

\subsubsection{Instrumentation and Control}

A. Instrumentation for the IDS shall be provided as required in the following paragraphs, and drawings $\mathrm{H}-4-34002$ and H-4-34003.

B. A replaceable leak detector shall be provided between the guard tank and the primary vessel.

C. A vertical row of thermocouples shall be provided on the external wall of the primary vessel for monitoring the vessel wall temperatures. 
D. Thermocouples shall be provided on the external side of the upper $3 \mathrm{ft}$ of the primary vessel wall to monitor the vessel temperature gradient near the sodium surface.

E. Thermocouples will be provided on the guard tank for preheat monitoring and control.

F. The temperature of the thermal shield will be monitored at the bottom plate and at the top plate of the reflective insulation. The temperature of the upper surface of the top shield will also be measured.

Thermocouples will also be used to monitor the temperature of the bearing and the drive motor.

G. The sodium level and temperatures will be monitored by inductive probes and thermocouples. (Additional thermocouples in the inlet and outlet lines are provided by System 81. )

H. The IDS drive control system shall have a semi-automatic mode so that when the operator manualiy selects the desired address at the control cabinet, correctly sets up all interlocks, and energizes the drive, the basket will be rotated to the proximity of the selected address without further operator action. Jogging of the controls may be necessary for the final positioning of the basket.

I. Deleted.

J. An independent system shall be provided to allow verification of the basket azimuthal position.

K. A control cabinet shall be provided from which storage positions may be selected and drive operation may be monitored. 
The control cabinet and controls shall conform to HWS-9347.

The cabinet shall contain, but not be restricted to the following:

1. Position Selector

2. Selection Verification Indicator (alphanumeric display of position selected)

3. Storage Basket Position Indicator

4. Operating Control Switches.

L. Deleted.

\subsubsection{Interface Requirements}

The IDS will interface with the following:

A. Floor Valve (System 41-7)--Any transfer port in the top shield shall mate with the adapter and provide a gas-tight seal.

The floor valve will rest on the adapter and complete the gas-tight enclosure.

The weight of the floor valve will be approximately 8-1/2 tons.

The combined load of the floor valve and adapter shall be carried by the impact absorber.

The top of the adapter shall be $550 \mathrm{ft} 3$ inch elevation.

The adapter and the IDS shall withstand the impact energy of mating parts without damage to the top shield assembly or loss of seal. 
The transfer ports shield plugs shall also be compatible with the floor valve passage diameter.

The CLEM, BLTC, and PHF will interface with the floor valve when performing transfer operations at the IDS.

B. CLEM (Closed Loop Ex-vessel Machine) (System 41-3)--The CLEM, which will transfer components between the reactor, the core component conditioning station, and the IDS, will mate with the floor valve.

The access ports in the top shield shall permit the passage of, and provide guidance for, the CLEM grapple.

The mateup load downward on the floor valve during transfer operations will be 40,000 1b. This load will be added to that of the floor valve adapter. Maximum impact load during mateup will be $1.65 \mathrm{~g}$.

The grapple of the CLEM, which engages the top of the core component transfer pot or the top of the test assembly, will be capable of exerting a maximum pull force (up) of 5,000 $\mathrm{lb}$ and a maximum push force (down) of 1,500 1b. The rotatable storage basket and supports, as well as the storage tubes, shall be designed for this load.

C. BLTC (Bottom Loading Transfer Cask) (System 41-11)--The rails for the BLTC Dolly (Drawing H-4-13052) will be extended over the top of the IDS.

The ports in the top shield shall permit passage of, and guidance for, the BLTC grapple. 
The combined weight of the BLTC and dolly is 151,000 1b. The cask weight is $100,000 \mathrm{lb}$ which must be supported by the floor valve and adapter.

The BLTC, mounted on its dolly, will travel on the equivalent of standard railroad gauge 171 lb track, which shall be installed in the impact absorber on the IDS shield. The dolly will have two axles and two wheels per axle with a wheel-base of $10 \mathrm{ft}$.

Routing of the track on the shield will be as shown on drawing $\mathrm{H}-4-13052$.

The maximum velocity of the BLTC dolly will be $15 \mathrm{fpm}$.

To reduce the spread of contaminants, "flow" of argon gas from the mating machine to the IDS will be permitted.

The rails must restrain the BLTC during seismic disturbances.

The BLTC grapple, which will engage the top of the core component during transfer operations, will be capable of exerting a maximum force (upward) of 1,500 1b and a maximum push (downward) force of 300 lb (grapple weight).

Interlock for the grapple up position must be provided.

D. PHF (Plug Handling Fixture) (System 41-8)--The plug handling fixture, which will be used for the removal and replacement of shield plugs, will rest on the floor valve and adapter.

The grapple pickup on the IDS top shield plugs shall be compatible with the PHF grapple.

The shield plugs shall be compatible with the PHF passage. 
The mateup load of the PHF, i.e., its weight, which will rest on the floor valve during plug handling operations, will be added to the weight of the floor valve and adapter.

The PHF, when being lowered into place on the floor valve, may impact the surface of the floor valve with a maximum acceleration of $0.25 \mathrm{gm}$.

The PHF grapple, which engages the grapple pickup on the shield plugs, will be capable of exerting a maximum pull force (upward) or $2,700 \mathrm{lb}$.

E. Railway Car with Maintenance Cask (System 44-2)--The railway car, with maintenance cask, will be partly supported by the IDS top shield.

The combined weight of the railroad car with the large maintenance cask will be 192 tons (50 tons of railroad car and 142 tons of cask with instrument tree).

The railroad car will travel on the same track as the BLTC Dolly. The maximum velocity will be $5 \mathrm{fpm}$.

The car is characterized by two trucks with a centerline spacing between them of $45 \mathrm{ft}$. Each truck has four axles and eight wheels with an axle centerline spacing of $5 \mathrm{ft} 6$ inches.

For dropped loads see Section 1.2.3 H.

F. IDS Cell (Area 546) (System 27)--The IDS is installed in Area 546 of the reactor containment building. This steel lined concrete cel1 is shown on drawings H-4-1306I and H-4-34097. 
The mechanical loads imposed on the cell by the IDS support structure are.

1. The static loads shall be determined by summation of the maximum weight of the structures and their contents.

2. Dynamic loads. See paragraph 1.2.10.C for the BLTC and paragraph 1.2.10.E for the railroad car with maintenance cask.

The temperature of the steel liner of the cell will be limited to $150^{\circ} \mathrm{F}$ during normal, upset, and emergency conditions.

A gas tight seal is required between the cell liner and the IDS support structure.

G. Radioactive Gas System (System 82)--IDS cover gas is provided from fresh argon supply and is exhausted to the cell atmosphere pressurization system (CAPS).

Argon gas requirements will be based upon the following:

1. Purging the cover gas once per fuel handling cycle - 2.8 times a year

2. Flow from CLEM and BLTC when transfers are being made 50 transfers per cycle

3. Services to buffered seals

4. Services to top shield and test positions

5. Normal purge 0.1 SCFM 
6. Both argon cover gas pressure control and emergency venting are provided by System 82 .

Physical access to the vapor trap compartment is provided by the IDS Support Structure $(H-4-34020)$. Cooling is provided by piped connections to cell atmosphere. Temperature readout and trace heating is provided by System 93-15.

H. Heating and Ventilating System (System 25)--The Heating and Ventilating System furnishes three distinct services to the IDS.

1. IDS Cell cooling which is part of the Inerted Cell Gas Cooling System $(H-4-11513$ and $H-4-11563)$

2. IDS vessel $\mathrm{N}_{2}$ Backup Gas Cooling System (H-4-11909 and H-4-11919)

Heat loses from IDS to the cell are a function of IDS sodium temperature only and are not sensitive to decay heat loads in the IDS. At $500^{\circ} \mathrm{F}$ the heat lost to the cell is $30 \mathrm{~kW}$.

It is imperative that cell cooling operate when the IDS vessel contains sodium. Portions of the upper part of the primary vessel are not insulated. These areas depend on cell cooling for temperature control. A lack of cell cooling will result in overheating of the IDS bearing, the support structure, and the cell walls.

The IDS Vessel $\mathrm{N}_{2}$ Backup Gas Cooling System is required as a normal operating alternate cooling system for IDS sodium temperature control.

This system must be available whenever the primary sodium circulation system is out of service. The cooling load to this 
system is a function of the decay heat load in the IDS. The cooling load can vary from zero to a maximum of approximately $125 \mathrm{~kW}$. When the decay heat load is below $30 \mathrm{~kW}$ at a sodium temperature of $500^{\circ} \mathrm{F}$, cell cooling dissipates the entire load (reference H\&I). At the maximum IDS decay heat load of $155 \mathrm{~kW}$, either the primary sodium cooling loop or the backup $\mathrm{N}_{2}$ cooling loop must dispose of approximately $125 \mathrm{~kW}$.

3. IDS Vessel Emergency Cooling--The IDS Vessel Emergency Cooling System is installed and may be activated by manual operation of four block valves if Containment is accessible. The IDS decay heat inventory is limited to $155 \mathrm{~kW}$.

I. Core Component Pot (System 41-9)--The IDS shall interface with the core component pots (drawing H-4-26085).

Transfer ports in the top shield shall allow passage of a core component pot into or out of storage with a maximum misalignment of the vertical centerline of the grapple, port, or storage tube of $\pm 1 / 4$ inch from true position.

The component pots shall be stored in the rotatable storage basket.

The pots shall be removable from the basket with the pull forces of the CLEM grapple.

J. Test Assemblies--System 61 (CLIRA) and System 31 (OTAs)--The IDS shall interface with the test assemblies to be stored therein as described in FRB 814 (W/723123), "CLIRA and OTA Interface Data" $(H-4-22106)$.

The test assemblies will have a maximum bow in the vertical altitude of 2 inches over the test assembly length. 
The ports in the top shield shall allow passage of a test assembly with a maximum misalignment and a maximum bow.

The test assemblies shall be removable from the IDS with the maximum pul1 forces of the CLEM grapple.

K. Main Control Room--Conduit and wiring from the IDS to the control room (not part of the IDS system) will be provided by others.

A single IDS alarm is provided on Panel C 136 in the main control room. This alarm is tripped by high- or low-sodium level, highor low-sodium temperature, an indexing fault, or a sodium leak to the guard tank.

L. Auxiliary Liquid Metal (System 81), Auxiliary Liquid Metal Instrumentation (System 93-10)--During normal operation, the sodium receiving and processing system will maintain the oxygen content in the sodium below $12 \mathrm{ppm}$. During operations, it may rise to $25 \mathrm{ppm}$ maximum for no more than $2 \mathrm{~d}$.

System 81 shall provide cooling to the IDS when the heat sources within the primary vessel exceed the heat losses to the cell and to containment. Level, flow, valve position, temperature, pressure, data logging, and leak detection instrumentation will be supp 1 ied by System $93-10$.

M. Inert Gas Receiving and Processing (System 82)--Argon for cover gas, start-up purging, and seal buffering will be furnished by System 82. Impure or radioactively contaminated gas which must be vented will be accepted and disposed of by System 82 .

N. Radiation Monitoring (System 96)--The plant radiation monitoring system will monitor for leakage of radioactive gases. 
0. Impurity Monitoring and Analysis (System 85)--Sodium will be monitored for plugging temperature by System 85 .

P. Communications (System 15)--Telephone equipment shall be provided for communication between the operator at the IDS control console and the operator at the IDS floor location.

Q. Heaters, Piping and Equipment Electrical Heating Control (System 93-15)--Vessel trace heaters are provided on the interior surface of the insulation facing the guard tank. These heaters will have the capability of preheating and maintaining the sodium temperature to the minimum operating requirement at times when the IDS decay heat load is insufficient to maintain sodium temperature. Thermocouples for preheat control are providad on the surface of the guard tank. Heater control is provided by System 93-15.

R. Leak Detector Readout (System 93-13)--Readout for the leak detector will be provided by System 93-13. Control room annunciators will be provided by System 93-14 (see H-4-34002).

\subsubsection{Quality Assurance}

A. Quality Assurance Program--A documented quality assurance program in accordance with Sections 1 through 5 and 8 of RDT F 2-2 will be followed.

B. Quality Assurance Documents--QA documents based on the requirements of RDT F 2-2 will be specified in the Specification HWS 1030 .

C. Traceability Documentation--Fabrication of the IDS shall be traceable to materials, heats, lots, processes, operators of special processes, inspectors, and drawings as required by Specification HWS 1030. 
D. Quality Records--Quality records are required for each component as specified in Specification HWS 1030.

E. Marking and Identification--All materials shall be marked for identification as specified in Specification HWS 1030.

F. Examination During Fabrication--All items shall be subjected to visual and dimensional examination to verify conformance with drawing requirements and the IDS Specification HWS 1030 .

G. Functional Testing--Tests shall be performed to demonstrate the operability of dynamic parts such as motors, gears, and bearings. These tests will be specified in the IDS Specification, HWS 1030.

H. Proof Tests--Proof tests shall be performed on, and documented for, all critical lifting, handling, supporting, and shipping fixtures prior to use on components. Specific requirements will be in the IDS specification HWS 1030.

\subsubsection{Codes and Standards}

A. Those parts of the IDS which form the pressure boundary for the containment of sodium and sodium vapor shall be constructed in accordance with the requirements of Section III, Class 1 , of the ASME Boiler and Pressure Vessel Code (herein referred to as the "Code") as supplemented by RDT Standard E 15-2T. Other parts must satisfy the requirements of Section VIII, Division 1 of the Code, or other appropriate specifications Code. The Code classification of specific components shall be as follows:

Support Structure

(Containment Boundary 0nly)
Section III, Class 1 , RDT Materials 
Top Shield Containment

Boundary On Ty)

Primary Vessel

Guard Tank

Rotatable Basket and

Storage Tubes

Floor Valve Adapter

Machinery Cavity Liner

Omega Seal
Section III, Class 1 , ASME Materials

Section III, Class 1, RDT Materials

Section VIII, Division 1

Section VIII, Division 1

Section III, Class 2, ASME Materials

Section III, Class 1 , RDT Materials

Section III, Class I, RDT Materials

B. Materials for the primary containment boundary shall be selected from those listed in RDT Standard E15-2T.

C. Gears and geared speed reducers (or increasers) shall comply with the requirements of the American Gear Manufacturers Association (AGMA).

D. Anti-friction bearings shall comply with the standards of the Anti-friction Bearing Manufacturers Association (AFBMA). 
SDD-41/5, Rev. 11

6-29-90

\subsubsection{Safety Assurance}

Application of safety assurance shall be based on Section F-4 of HEDL-TME 71-150, Volume 1, "Safety Assurance Summary". 


\subsection{DESIGN DESCRIPTION}

This section of the SDD provides design characteristic details of the various components that make up the Interim Decay Storage (IDS) facility.

\subsection{SUMMARY DESCRIPTION}

The IDS facility is located between the CLEM rails and within the FFTF containment building. It is located in a rectangular steel-1ined concrete cell which lies entirely below the $550 \mathrm{ft}$ floor level with the top flush with the $550 \mathrm{ft}$ floor level. The BLTC rails within containment traverse ihe IDS cover (H-4-38001).

The facility consists of a rotatable storage basket submerged in liquid sodium which is contained in a stainless steel tank. The storage positions within the basket are arranged so that it is not physically possible to achieve a critical array. The primary vessel is enclosed in a secondary guard tank of such size and arrangement that, should a leak develop in the primary tank, the sodium level would not fall below the top of the fueled section of the stored core components or test assemblies. The atmosphere outside the primary vessel, but within the concrete cell, is nitrogen which also serves as a heat transfer medium to control the cell temperature.

To provide space for the storage of test assemblies such as the OTA and CLIRA, 10 storage tubes (each approximately 43-1/4 ft long) are included near the center of the basket. This arrangement requires that the center of the primary vessel be quite deep. In this region, the primary vessel extends downward to elevation $501 \mathrm{ft} 6$ inches while the guard tank reaches $500 \mathrm{ft} 4$ inches. The floor of the cell is at $499 \mathrm{ft} 0$ inches which is $51 \mathrm{ft}$ below the operating room floor. 
Storage positions are provided for 112 core components in the upper section of the storage basket. These positions are arranged in four circles, all of which are concentric with the test element array and the storage basket. The primary vessel and the guard tank are shaped to provide the necessary space with a minimum of excess volume. Both these vessels have a relatively small cylindrical lower section connected to a larger upper cylinder by a conical transition.

The primary vessel is supported from a top flange by a vessel support structure. The guard tank is supported by a skirt which rests on a ledge at elevation $527 \mathrm{ft} 2$ inches. The skirt is an extension of the upper cylinder of the guard tank. The storage basket is supported by a gear-driven, mechanically indexed, ball bearing that rests on the bearing support, which in turn rests on the vessel support structure.

The interior of the primary vessel above the sodium level is blanketed with argon at 6 inches of water gage pressure. The vessel is designed to allow the pressure to be increased to 3 psig to assist drainage of the sodium from the vessel.

The structure which supports the primary vessel also serves as the cover to the IDS cell. The support structure rests on a shelf cast into the cell wall at the $544 \mathrm{ft} 6$ inch level. In addition to supporting the primary vessel and the storage basket bearing, this structure also provides support for the top shield which is a 16 inch thick by $15 \mathrm{ft} 10$ inch diameter laminated steel assembly, which in turn supports the impact absorber neutron shield, and the BLTC tracks where they cross the IDS.

Storage position access ports are provided on the centerline of the IDS facility between the BLTC rails. Basket rotation and indexing allows any storage position to be located in alignment with its proper access port.

Double buffered seals are provided for the removable plugs and removable lids for all components and access ports where necessary to seal between the 
vessel cover gas and the FFTF containment atmosphere. Buffering gas for these seals is argon. Capability of a $10 \mathrm{cfm}$ argon purge rate is provided although normal argon flow into the cover gas cavity will be less than $1 \mathrm{cfm}$. Argon cover gas exits through a vapor trap located in the southwest corner of the support structure and then to the Cell Atmosphere Processing System. Vessel overpressure protection is provided by rupture discs on the inlet and outlet argon piping. Rupture discs vent to the IDS cell.

Biological shielding is provided to maintain the radiation contribution in the operating area below $0.2 \mathrm{mrem} / \mathrm{h}$. The primary gamma shield directly above the IDS is the 16 inch thick steel top shield and the 4 inch steel striker plate. Neutron attenuation is provided by 4 inches of polyethylene directly below the impact absorber tubes.

Control instrumentation and power junction boxes are provided in the top cover. Instrumentation includes basket position sensor and indicator, interlocks, thermocouples, sodium level indicator, sodium leak detector, and a cover gas pressure indicator. Means for visually checking the position of and manually rotating the storage basket are also provided.

Decay heat is dissipated during normal operation by either the primary sodium system or the backup nitrogen cooling system. The sodium system circulates approximately $30 \mathrm{gpm}$ of sodium from near the top of the primary vessel to an intermediate heat exchanger and returns the cooled sodium to near the bottom of the vessel. A branch system is provided to divert $15 \mathrm{gpm}$ to a sodium cold trap for purification and $3 \mathrm{gpm}$ to a plugging temperature indicator for analysis. The backup or standby $\mathrm{N}_{2}$ cooling system circulates cooled nitrogen into the top of a cooling annulus which is formed by the guard tank and the insulation. The heated nitrogen is returned from the bottom of the annulus to the nitrogen-mobiltherm heat exchanger. Either of these cooling systems will maintain the IDS and its charge of test assemblies and core components below the maximum allowable temperature. 
SDD $41 / 5$ Rev 11

6-29-90

Figure VII. Interim Decay Storage Assembly

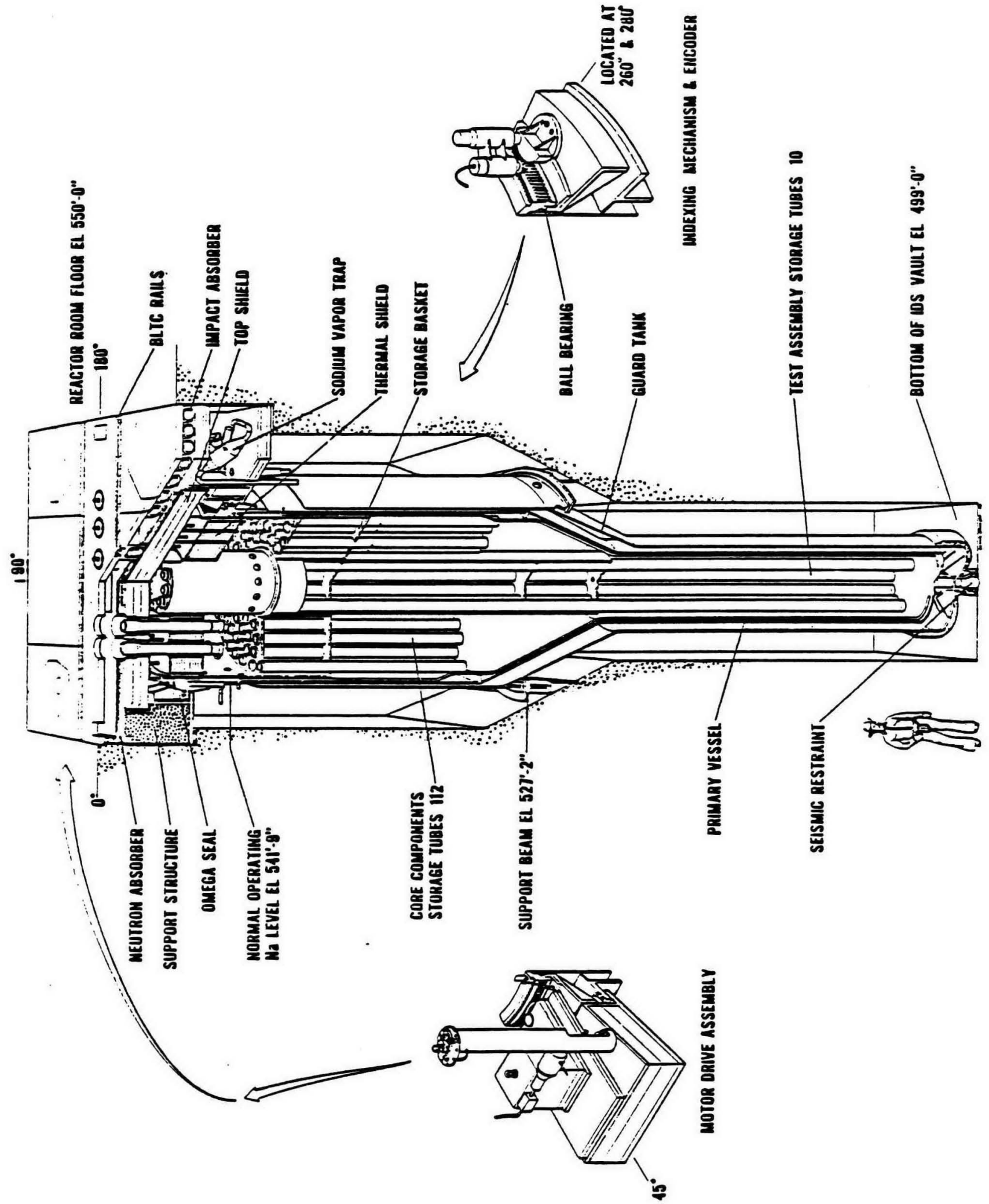


An emergency convective cooling system which will limit the IDS sodium temperature in the event of a complete power failure is also provided. The IDS Vessel Emergency Cooling System is installed and may be activated by manual operation of four block valves if containment is accessible. The IDS decay heat inventory is 1 imited to $155 \mathrm{~kW}$.

\subsection{DETAILED DESCRIPTION}

\subsubsection{Primary Vessel (H-4-34079)}

The principal function of the primary vessel is to contain the sodium coolant and to confine the radioactive contaminants within the primary system. In conjunction with other parts of the facility, it provides a gas-tight inert environment to assist in maintaining the sodium purity.

The primary vessel houses the storage basket that provides vertical storage tubes for 112 core components, each $12 \mathrm{ft}$ long, and 10 test assemblies, each $\leq 42 \mathrm{ft}$ long. These storage tubes are arranged in five concentric circles with the long tubes nearest the center and the shorter tubes in the four outer rows. The test element storage tubes are positioned vertically so that they extend approximately $25 \mathrm{ft}$ below the shorter tubes; the primary vessel was designed to accommodate them and also to minimize the total quantity of sodium required. This resulted in a vessel with a long lower section of relatively small diameter attached to a shorter upper section of larger diameter with a conical transition joining the two cylindrical sections. The lower cylinder is approximately $19.75 \mathrm{ft}$ long, 60 inches ID, with a $9 / 16$ inch wall. The bottom head is a 60 inch ID, 2 to 1 ellipsoid $5 / 8$ inches thick. The upper section is a cylinder $12.5 \mathrm{ft}$ diameter $12 \mathrm{ft}$ long with a $9 / 16$ inch thick wall except for the upper 18 inches which has a wall thickness of 2 inches. This thickened section provides stiffness in the area where the $14.66 \mathrm{ft} O D$ support $r i n g$ is attached. The transition between these two cylinders is a frustum of a cone with a reinforcing ring welded to 
the large end. The conical section is approximately $6 \mathrm{ft} 5$ inches high and has a $9 / 16$ inch wall.

The vessel is penetrated by three 2 inch nominal pipe size nozzles for sodium inlet, outlet, and drain and two of the same size for argon inlet and outlet.

A pin approximately 11 inches diameter, is attached to the cell floor on the vessel centerline to provide seismic restraint. A matching pin of the same diameter is attached to the bottom of the primary vesse1. Sockets which mate with both pins are attached to the inside and outside of the guard tank at its bottom head.

This vessel is designed, fabricated, welded, tested, and inspected to comply with ASME 1971 Code, Section III, Class 1, and RDT E 15-2T, dated July 1971. The exterior surface of the vessel is to be finished with a surface which will assure an emissivity of 0.4 minimum.

\subsubsection{Guard Tank (H-4-34086)}

The guard tank is a vertical, open-top tank which surrounds the IDS primary vessel and acts as a secondary containment for the sodium coolant. The size and physical dimensions of the guard tank are such that, in the event of a leak in the primary vessel, the sodium level would not drop low enough to expose the fueled portion of the core components and test assemblies which are stored in the IDS facility. The guard tank will contain sodium only in the event of a failure of the primary vessel. The guard tank, like the primary vessel, consists of a long cylindrical lower section connected to a larger diameter, shorter upper cylinder by a conical transition piece.

The lower section is a 72 inch ID cylinder approximately 20-3/4 ft long with a $1 / 2$ inch wall. The lower head is a 72 inch ID, 2 to 1 ellipsoid 
$1 / 2$ inch thick. The upper cylinder serves a dual purpose. The upper

$12 \mathrm{ft} 2$ inch forms the upper cylinder of the tank and the lower 15-5/8 inch forms the support ring for the entire vessel. To allow for circulation of cooling gas, there are sixteen 8 inch diameter holes in the support skirt.

A seismic restraint sleeve is attached on the vessel centerline at the bottom head, both inside to mate with the primary vessel pin and outside to mate with the restraint pin set into the cell floor.

The guard tank has no penetrations and only one internal attachment, a $7 / 8$ inch $O D$ tubing which houses a sodium leak detector probe. The bottom head of the guard tank is insulated by material attached directly to the vessel. All other insulation is provided and supported by the cell.

The guard tank is fabricated of ASME SA516 carbon steel and is required to meet the fabrication, welding, testing, and inspection requirements of the 1971 Edition of the ASME Code, Section VIII, Division 1. Both exterior and interior surfaces of the guard tank must have a finish which will provide an emissivity of 0.66 minimum.

\subsubsection{Support Structure (H-4-34020)}

The support structure is required to support all major components of the IDS facility (except the guard tank) plus the full load of reactor core components, test assemblies, and the sodium coolant which will be contained in the primary vessel. In addition, the support structure must support external loads such as the floor valve adapter, the BLTC, the PHF, or the maintenance cask.

The support structure is square in outside plan, $20 \mathrm{ft}$ on a side. It is 46 inches deep with circular penetration in the center which varies stepwise from $12 \mathrm{ft} 10$ inches to $16 \mathrm{ft} 4$ inches diameter. The structure 
itself rests on four self-lubricated bearing plates which are in turn supported on a shelf cast into the cell wall.

From the various steps in the center, the support structure will support the primary vesse1, the basket bearing support, the top shield, the neutron shield, the impact absorber, the striker plate, the BLTC rail and rail support, and eventually the larger items listed in the first paragraph.

There are stiffener plates between the outer square and inner cylinder of the support structure. The cavities thus formed, except for five on the corners, are filled with concrete. Two cavities at the northeast corner are used for the motor drive pit and the electrical and instrument terminal connector pit. The cell access opening is through the cavity in the northwest corner, and the vapor trap is housed in the southwest corner.

The interior of these cavities in the support structure is 1 ined, in part, by lead, polyethylene, or both to replace the shielding which would have been provided by the concrete.

The bottom surface of the support structure is formed by a 2 inch thick plate which also acts as the support ledge for the primary vessel. All of the cylindrical surfaces above the bottom plate and the motor drive pit form a part of the sodium-argon boundary and must be designed and fabricated to the requirements of Class 1 , Section III, of the ASME Code as supplemented by RDT E 15-2. The remainder of the support structure must meet the requirements of Section VIII, Division I, of the ASME Code. The structural components of the support structure will be ASME SA-516 carbon steel.

\subsubsection{Top Shield (H-4-34054)}

The top shield is a laminated carbon steel disc 16 inches thick and $15 \mathrm{ft} 10$ inch diameter. In addition to acting as the pressure containment cover for the primary vessel/support structure, it is the principal gamma 
shield between the IDS and the reactor room operating floor. It al so supports the thermal shield and the impact absorber. The top shield acts as the structural support which transmits the load of the floor valve adapter, the floor valve, the BLTC, the PHF, and the maintenance cask to the support structure when these devices are in their operating position.

The top shield is penetrated in nine places by access plugs. Five of these are on the north-south centerline and provide access to the five rows of storage positions in the basket. Two are aligned with Row $E$ of the storage basket west of the north-south centerline of the IDS approximately 18 inches to each side of the east-west centerline. These ports are used principally as instrument and lighting ports. The northern position is used for the sodium level sensing element and the southern one is for a lighting and viewing port.

The remaining two penetrations are located on the west side of the north-south centerline above the basket support bearing and are used for access to basket position sensing devices. All of the plugs which fit the penetrations through the top shield are sealed with double "0" ring seals with argon gas buffering between them. These double buffered seals form a part of the pressure boundary for the IDS.

A11 of the penetration plugs for the top shield are a part of the pressure boundary of the IDS. They were designed, welded, and fabricated to comply with ASME Code, Section III, Class I, as supplemented by RDT E 15-2.

The joint between the top shield and the support structure is also a part of the pressure boundary. It is sealed by two pairs of " 0 " rings with argon buffering. These seals are compressed against a $15 \mathrm{ft} 6$ inch inside diameter by $4-7 / 8$ inch wide seal ring. The seal ring is a part of the pressure boundary of the IDS system. It is ASTM A516 Grade 55 Steel and is designed, fabricated, and welded to comply with ASME Section III, Class I, and RDT E 15-2. 


\subsubsection{Omega Seal (H-4-34096)}

The omega seal is a formed ring which acts as a seal and pressure boundary between the primary vessel and support structure. Since it is a part of the pressure boundary of the IDS system it is designed, fabricated, welded and tested to comply with ASME Section III, Class I, of the ASME Code, and RDT E 15-2.

This seal has a modified omega shaped cross-section formed into a ring having a $14 \mathrm{ft}$ 9-1/8 inch outside diameter and a $13 \mathrm{ft} \mathrm{9-1/16} \mathrm{inch} \mathrm{inside}$ diameter. This device was fabricated from 304 stainless steel sheet, meeting the requirements of the RDT M 5-1T. The outer edge of the ring is welded to a nickel alloy weld boss which was deposited on the support structure and machined to proper size and configuration. The inner edge is welded to the primary vessel flange, providing a seal between the two components.

\subsubsection{Storage Basket (H-4-34050)}

The storage basket is a vertical cylinder which supports 112 storage tubes for FFTF core components and core component pots (CCP) and 10 storage tubes for FFTF test assemblies. The core component storage tubes are arranged in four concentric circles. The outer circle contains 40 positions on a $9 \mathrm{ft} \mathrm{11-1/2}$ inch diameter circle. Subsequent inner circles accommodate 32 , 24, and 16 positions on diameters of $8 \mathrm{ft} 3.584 \mathrm{inch}, 6 \mathrm{ft} 7.667 \mathrm{inch}$, and $4 \mathrm{ft} 11.75$ inch, respectively. The 10 test assembly storage tubes are arranged concentrically about the basket centerline on a 33.5 inch diameter circle.

The core component storage tubes are $12 \mathrm{ft} 4$ inches long and 8 inch $0 D$. They are supported from the top by a $1-1 / 2$ inch thick by $9-15 / 16$ inch $0 D$ flange. The bottom of the storage tube is $1-3 / 4$ inch thick with a $1 / 8$ inch diameter hole on its centerline. The lower 18 inches of these tubes are reduced in the inside diameter to act as a hydraulic snubber in the event a 
core component storage pot should be inadvertently dropped while being inserted or removed.

The storage basket is an $11 \mathrm{ft} 5$ inch ID cylinder which is formed from $3 / 8$ inch thick stainless steel plate, $10 \mathrm{ft}$ long. A 1 inch thick plate is welded across this cylinder 65-1/2 inches below the upper edge, and a $1 / 2$ inch thick plate is welded across the bottom of the cylinder.

Both of these plates are perforated with 1128.1 -inch diameter holes on the four previously described circles and with a center hole 45-1/2 inch diameter. The two plates are connected on the periphery of the center hole by a 3/8 inch thick cylinder, 45-1/2 inch ID. The smaller holes are arranged so that each hole in the upper plate has a corresponding hole on its vertical centerline in the lower plate. A core component storage tube is placed through each plate so that it is supported by the upper plate and held in vertical alignment by the lower.

A $34 \mathrm{ft}$ long cylinder which is 44-1/2 inch $O D$ is inserted through the center hole in the basket. This cylinder is supported by a $1-1 / 2$ inch thick ring, 49-1/2 inch $0 D$, which is attached to the center cylinder $6 \mathrm{ft}$ from its upper end and rests on the upper basket plate. A 1 inch thick plate is welded across the top of the center cylinder. It is 44-1/2 inch 00 and has 10 equally spaced 8-1/8 inch holes on a 33-1/2 inch circle. Directly below this upper plate is suspended a reflective insulation assembly of 4016 gage stainless steel sheets spaced at 0.6 inch vertically and perforated with 10 holes 8-5/8 inch diameter on a 33-1/2 inch circle. The test assembly storage tubes are inserted through these holes into the center cylinder. These tubes are $42 \mathrm{ft} 6$ inches long, 8 inch 0D, with 0.12 inch thick walls except for the upper section of approximately $2 \mathrm{ft}$ which is $1 / 2$ inch thick. The upper end of this thickened wall is bored out to a depth of $4-13 / 16$ inch to provide a surface to support the test assembly.

The upper end of the storage tube is terminated in a flange which is $9-15 / 16$ inch $O D$ and 1 inch thick. The storage tube is supported by this 
flange. The lower end of the test assembly storage tube contains a hydraulic snubber to absorb the energy of a dropped test assembly. Sodium circulation holes are provided in the test assembly storage tube both above and below the fueled portion.

Three supplementary guide plates are provided in the inner storage basket to position the test assembly storage tubes. These are located $10 \mathrm{ft} 6$ inches and $22 \mathrm{ft} \mathrm{2-3/4}$ inches below the upper end and at the bottom of the inner storage basket.

Sodium circulation holes are also provided in the cylinder of the inner storage basket. These holes are located approximately 4 inches above the support ring for the inner storage basket.

The storage basket is attached to the ball bearing assembly which allows it to rotate so that the desired storage position is aligned with its proper seal port. To reduce thermal stresses between the basket, which is stainless steel, and the bearing, which is carbon steel, a transition piece of Inconel has been used. This Inconel transition piece is attached to the basket by welding and by bolting to the bearing.

The storage basket is designed and fabricated to comply with ASME Boiler and Pressure Vessel Code Section III, Class 2. Materials of construction are Type 304 stainless steel meeting the requirements of RDT M 5-1T, and nickel alloy per RDT M 5-4.

\subsubsection{Bal1 Bearing (H-4-34018)}

The ball bearing supports and permits rotation of the storage basket. The bearing is, in turn, supported by the bearing support and ultimately by the support structure. The force which causes the bearing and the basket to rotate is applied by the drive train to a bull gear which is an integral 
part of the upper race of the bearing. The basket is bolted to the inner part of the upper race.

The bearing itself is a nominal 144.25 inch diameter with the upper and lower races designed to provide a functional interlock to prevent lifting forces or seismic overturning moment from separating the assembly. There are approximately 150 balls with a minimum diameter of $1-3 / 8$ inch.

The integral bull gear has 445,3 -inch wide teeth on a 148.333 inch pitch diameter. A 2,944 tooth instrument gear is machined into the outer surface of the upper race. The principal function of the instrumentation gear is to sense the location of the basket with respect to the access ports in the top shield.

The bearing balls for this assembly are of AISI E52100 alloy steel, hardened to 60 to 67 Rockwell C. The bearing races are of steel which is surface hardened to 58 to 62 Rockwe $11 \mathrm{C}$, and both gears are hardened to 212 to 248 Brinne11. Labrinth seals are provided on each side of the bearing races to prevent entrance of foreign material into the raceways.

\subsubsection{Drive Train}

The drive train consists of an electric motor and a speed reducer of the double reduction worm gear type which drives a 3 inch wide, 14 tooth spur gear which in turn drives a 3 inch wide, 48 tooth idler gear. The idler gear drives an identical output gear which meshes with the ball bearing assembly bu11 gear. The speed reducer has a 600 to 1 ratio. It is driven by a $1,750 \mathrm{rpm}, 1$ to $1 / 2 \mathrm{hp}$ electric motor. The output shaft of the gear reducer rotates at $2.9 \mathrm{rpm}$.

The drive train is mounted in the motor drive pit which is located in the northeast corner of the support structure. The mounting base is arranged so 
that the drive train assembly may be removed for maintenance and replaced with sufficient accuracy to permit proper mating with the bull gear.

To prevent worm gear lubricant from falling into the IDS sodium, a special pan is installed under the seal on the gear reducer output shaft. The capacity of this pan is greater than the capacity of the gear box. Gears outside of the speed reducer are lubricated with a dry film lubricant (such as Dow-corning "Molykote $X-15 "$ ).

In addition to the motor drive, a normaliy disengaged manual drive is incorporated into the design of the drive train assembly. By means of this connection, it is possible to rotate the storage basket to any desired position without electrical power. This permanently installed flexible shaft may be connected to the drive motor output shaft to apply motive power to the drive train. This assembly is also lubricated with the same dry film lubricant as the spur gear and idlers.

\subsubsection{Thermal Shield (H-4-34065)}

The thermal shield is a set of 40 parallel stainless steel sheets which are suspended from the top shield of the IDS facility. It is intended to restrict the flow of heat from the molten sodium in the primary vessel to the reactor room operating floor.

The thermal shield is composed of 40 reflective sheets, $11 \mathrm{ft}$. 3-1/2 inch OD of 0.063 inch thick ASME SA 240, Type 304 stainless stee 1 with an ASTM A480, No. 4 finish on both sides, and one $1 / 2$ inch thick plate of the same outside diameter and material. These parts are penetrated by: one 46-1/2 inch diameter hole at the center, four approximately 11-5/8 inch diameter holes on the north-south centerline, and two 11-3/4 inch holes 18 inches from the east-west centerline and 57.04 inches west of the north-south centerline. The large hole in the center accommodates the center portion of the rotating basket; the four holes on the north-south centerline 
are for storage tube access; and the two west of the $\mathrm{N}-\mathrm{S}$ centerline are for lighting and viewing ports and for the sodium level and temperature monitors.

In addition to these major holes, there are 48 holes in each plate for supports and one through all the sheets for thermocouples. The holes for the supports are approximately 2-3/4 inch diameter. The thermocouple hole is 2 inches.

The reflective plates are supported on 2 inch Schedule 40 pipe which are welded to the top plate of the assembly. The plates are spaced on the supports by $3-1 / 2$ inch $O D \times 0.6$ inch thick spacer washers.

To minimize argon thermal convection and the accompanying sodium frost up the center tube and then horizontally across the top of the thermal insulation, inner and outer vertical baffles are positioned between the top shield and the upper surface of the insulation.

The thermal shield is designed and fabricated to comply with the requirements of Section VIII of the ASME Boiler and Pressure Vessel Code.

\subsubsection{Bearing Support (H-4-34076)}

The bearing support is a circular carbon steel weldment, essentially cylindrical with a ring at the top and near the bottom.

The maximum diameter is that of the top ring which is $15 \mathrm{ft} 1-11 / 16$ inch $O D$ and $14 \mathrm{ft} 3 / 8$ inch ID. This ring is cut from $1-3 / 4$ inch thick plate. The cylindrical portion of $14 \mathrm{ft} 9-1 / 4$ inch $0 D, 1-1 / 2$ inch thick, and 20-3/4 inch 7ong. The ring which forms the bearing seat is welded to the inside of the cylinder with the top surface 13-1/2 inches below the top of the cylinder. The inside diameter of the support ring is $11 \mathrm{ft} 6-3 / 4$ inches. It is cut from 2-1/4 inch thick plate with the upper surface machined to 2 inches thick in a $12 \mathrm{ft} 9-3 / 4$ inch circle to provide a flat, smooth surface for the 
bearing. For added rigidity, 23 pairs of gusset plates are welded between the cylinder and the bearing seat from both above and below.

The entire assembly is supported by the outer 2 inches of the top ring which rests on a corresponding surface in the support structure at an elevation of approximately $546 \mathrm{ft} 11$ inches.

A 30 inch wide by 11-1/4 inch high opening is provided through the cylinder in the northeast quadrant for the insertion of the drive train assembly.

\subsubsection{Storage Basket Index}

2.2.11.1 Electrical Indexing Encoders (H-4-34036). The true position of the IDS storage basket is sensed and the position indicated by either of two storage basket indexing assemblies, one of which is the control encoder and the other the verification encoder. Both encoders will generate a signal which will uniquely indicate any of 114 discrete basket locations. These addresses correspond with one or, in eight cases, two storage tube access port alignments.

The signal from the encoders will be transmitted to the indexing control panel which is mounted on Control Panel C625 (paragraph 2.2.12.d) where it is utilized for basket control functions and status indication.

The encoders are mounted on stands which are attached rigidly to the bearing support assembly. The mount is held by spring tension in such a position that the sensing gear meshes with the instrument gear mounted on the top of the upper race of the basket support bearing. Calibration is by remote electrical bias of the output voltage.

The basket position encoder is capable of sensing 8192 discrete positions and of reporting with an accuracy of plus or minus one position. This amounts 
to $3 / 64$ inch on the outer ring of storage tubes. The uncertainty is relatively less for the inner rings of storage tubes.

2.2.11.2 Visual Index (H-4-38020). The visual indexing assembly is an optical device which can be used to determine the position of the storage basket independent of the encoders. This device consists of a front surface mirror and two light sources and a structure to position them. A sealed viewing window is mounted in the drive pit cover. This arrangement allows the alignment of a pointer and position tab to indicate the basket orientation.

Best lighting and visibility of the pointers is provided by use of a flashlight illuminating the index pointers via bounced light from the mirror. Accordingly, replacement of the light bulbs within the pressure boundary is not anticipated.

The visual index device may be removed from the drive pit cover for replacement of light bulbs or other maintenance procedures but a special, sealed maintenance enclosure will be required. Both the flange which supports the visual index structure and the sight glass are sealed by buffered seals which form a part of the pressure boundary. Both seals are buffered by argon supplied by $1 / 4$ inch HCD 41021 and controlled by Valve V-4132. Flow rate is monitored by $\mathrm{Fl}-4104$ in Terminal Pit 3 . The visual index assembly viewing tube flange with window attached conforms to ASME Class I, Section III, as modified by RDT E 15-2.

\subsubsection{Control Cabinet (H-4-34034 and H-4-34042)}

Control Cabinet C625 is located on the $550 \mathrm{ft}$ level in the northeast quadrant of the FFTF containment vessel. The cabinet to be used is a standard Honeywel1 Series 4000 equipment rack which accommodates 19 inch wide modules. The rack is approximately $7 \mathrm{ft}$ high. 
Mounted in the cabinet are the following modules:

A. Annunciator panel with alarms for high or low sodium level, high or low pool temperature, indexing system fault, and high argon supply life pressure.

B. Access plug monitor panel which indicates the condition of the storage position access plugs and provides for inputting to the system the location of the floor valve to be used for the next accessing operation.

C. Process monitor panel with meters indicating sodium leve1, pool temperature, and cover gas pressure. A recorder is mounted on this panel to record the same parameters.

D. Indexing control panel with a means for indicating the desired basket address, an actual basket address read-out, an interlock status indicator display for each of the devices which will interact with the IDS, and various control switches. This control panel contains all the control and analysis functions for the IDS indexing system.

E. A 24 Vdc power supply.

\subsubsection{Floor Valve Adapter (H-4-34070)}

The floor valve adapter is in the form of a pipe stub $14-1 / 2$ inch $O D$ and approximately 25-1/8 inches long with an approximately 2-1/2 inch thick flange on one end and a pair of " 0 " ring grooves on the other. The $f 1$ ange is rectangular in plan, 48 inch $\times 57$ inch, and symmetrical about both centerlines. The center of the stub pipe coincides with the intersection of the $f 1$ ange centerlines. The inside diameter of the pipe is 11.250 inches. 
The upper surface of the $f 7$ ange is machined to a 32 microinch surface to a diameter of 26-3/4 inches. Outside this central surface, the flange face is relieved .375 inch to a diameter of $42-3 / 4$ inches and beyond that relieved .170 inch more to a diameter of 55.03 inches. Beyond this faced area, the flange is full thickness.

From the outside of the pipe, the flange is relieved from the back face approximately $5 / 8$ inch to a diameter of 26 inches. From this point outward, the back is machined to a surface which is 2.25 inches below the plane of the central portion of the flange face. The flange is then drilled and tapped from the rear face to allow the attachment of a steel spacer and shield piece.

The floor valve adapter fits into the access port sleeve far enough that the two "0" rings near the extreme end of the nozzle form a buffered seal with the access port sleeve. Argon for buffering this seal is introduced through a port in the access port sleeve.

Pressurization of the seal assures the integrity of the argon blanket. The buffered seals of the lower surface of the floor valve mate with inner raised face of the floor valve adapter.

Since the floor valve adapter forms a part of the IDS pressure boundary, it is designed to meet the requirements of the ASME 1971 Code, Section III, Class 2.

\subsubsection{Electrical and Instrumental (H-4-34012)}

Electrical/instrumentation connections are made through three terminal pits. Terminal Pit 1 is to the west of the drive motor pit in the northeast corner of the support structure. Terminal Pit 1 and the drive motor pit lie inside the IDS pressure boundary so that any penetration through the north wall of either of these pits must conform with the requirements of ASME 1971 Code, Section III, Class 1, as supplemented by RDT E 15-2T, 
All instrumental/electrical connections to the drive motor pit, Terminal Pit 1 , and visual index assembly are made from Terminal Pit 2 which is located outside the pressure boundary at the northeast corner of the IDS and adjacent to the north wall of both pits. All other connections are routed through Terminal Pit 3 which is located at the southwest corner of the IDS outside the pressure boundary. These other connections are of two types: (a) those which penetrate into the areas which are cooled and blanketed by nitrogen and (b) those which are connected into the normal containment atmosphere. Type "a" must meet the requirements of ASME 1971 Code, Section VIII, Division 1. There are no special sealing requirements for Type "b" penetrations.

The following electrical or instrumentation services or functions are provided for the IDS:

A. Power to the drive train motor--from Motor Control Center B18

B. Four thermocouples on the bearing race--connected to Panels C 875 and $\mathrm{C} 850$

C. Two thermocouples on the drive train motor--connected to Panels C875 and $\mathrm{C} 850$

D. Twelve themocouples on the thermal shield--connected to Panels C875 and $\mathrm{C} 850$

E. Visual index assembly light--from Motor Control Center B18

F. Six thermocouples on the guard tank--to Panels C875, C884, and C850 
G. Thirty-two thermocouples on the primary vessel--to Panels c875 and $\mathrm{C} 850$

H. Two thermocouples on the sodium inlet nozzle to the primary vessel--to Pane] C875

I. Two encoders--to Panel 6675

J. Two level detectors--to Panel C625

K. Two sodium pool thermocouples--to Panels C625 and C312

L. Leak detector--to Panel C1209

M. Vapor trap and IDS heat trace wiring--to Panels C835 and C875

N. Communication service--to Telephone Distribution Cabinet No. 12

0. Two vapor trap thermocouples--to Panels C875, C884, and C850

P. Drive motor control--Panel C625 to Motor Control Center B18

Q. Alarm, IDS general--Panel C625 to Panel C136, actuated by high or low sodium level, high or low sodium temperature, index system fault, or a sodium leak to the guard tank.

R. Sodium process control--from Panel C625 to Panel C312 (Plugging Temperature Indicator $\mathrm{N}-48$ readout on Pane $1680 \mathrm{~A}$ )

S. Pressure switches--to Panel C625, indicates shield plug not in place

T. Interlock IDS to CLEM or BLTC--to Panel C625

U. Four thermocouples on the top shield--to Panels C875 and C850. 
Note that item "A" requires a through-bulkhead connector between Terminal Pit 2 and the motor drive pit. Items " $B$ ", " $C$ ", and "D" require 18 through-bulkhead connectors between Terminal Pit 1 and Terminal Pit 2. There are also six spare through-bulkhead connectors between Terminal Pits 1 and 2. All of these connectors penetrate the pressure boundary and, therefore, must satisfy the requirements of ASME 1971 Code, Section III, Class 1, and RDT E 15-2T.

\subsubsection{Impact Absorber (H-4-34024)}

The impact absorber is a system of 4 inch thick striker plates supported either by the rail support crush tubes or by one rail support tube and a series of shorter crush tubes arranged along the east and west edge of the IDS cover assembly. There are 15 penetrations through the striker plate. All except the vault access openings are small and are covered by plates which transfer all loads to the striker plate. The vault access opening is large enough (approximately $46 \times 48$ inches) to require its own crush tubes. The vault access opening cover is supported normally by the western striker plate. It is provided with 4 captive crush tubes which allow approximately 0.06 inch deflection of the main striker plate before assuming any load directly applied to the access cover.

Loads on the BLTC rails are transferred directly through the rail support crush tubes to the top shield. Loads on the other crush tubes are transferred from the striker plate to the neutron absorber by the crush tubes and by the neutron absorber to the top shield.

To absorb horizontal thrust loads imposed on the striker plate, a system of 16 seismic restraint devices have been provided. These are located in groups of 4 near the edges of the striker plate, arranged symmetrically about both north-south and east-west centerlines. 
All three sections of the striker plate and the two BLTC rails are bolted together so that the entire assembly will react as a unit to horizontal forces and all 16 seismic restraints will act to transfer the load to the support structure.

\subsubsection{Argon Tubing and Manifold (H-4-34039)}

Argon flow is controlled and monitored by valves and flow indicators which are mounted in Terminal Pit 3 which is near the west corner of the south side of the IDS cover. The individual tubings leave the terminal pit over the top of the support structure in a 1-1/2 inch deep by approximately 14 inches wide relief in the neutron absorber. This relief extends to a point over the top shield where the relief is milled into the top shield, leaving the neutron shield at its full depth. Where these lines cross the top shield, seal ring line No. 1/4 inch HCD 41027 is connected to the buffer space in the seal between the support structure and the seal ring. Other lines go to seals in the nine access plugs or across the top shield to the buffered seals on the motor drive pit cover, the No. 1 terminal pit cover, and the two openings in the motor drive pit cover.

The access plug seal, sleeve seal, and floor valve adapter seal tubing and valve relationship is listed in Table III.

\subsubsection{Neutron Absorber (H-4-34046)}

The area under the striker plates and crush tubes is covered by a nominal 5 inch thick layer of polyethylene which is enclosed on all sides by $1 / 2$ inch carbon steel plates. As with the striker plate, the neutron shield is separated by the BLTC rails into three main sections. The eastern section is divided so that the drive motor pit and Terminal pit 1 may be uncovered by removal of a single block approximately $5 \mathrm{ft}$ 10-1/2 inch by $6 \mathrm{ft}$ 6-1/4 inch. The western section is arranged similarly with a single 


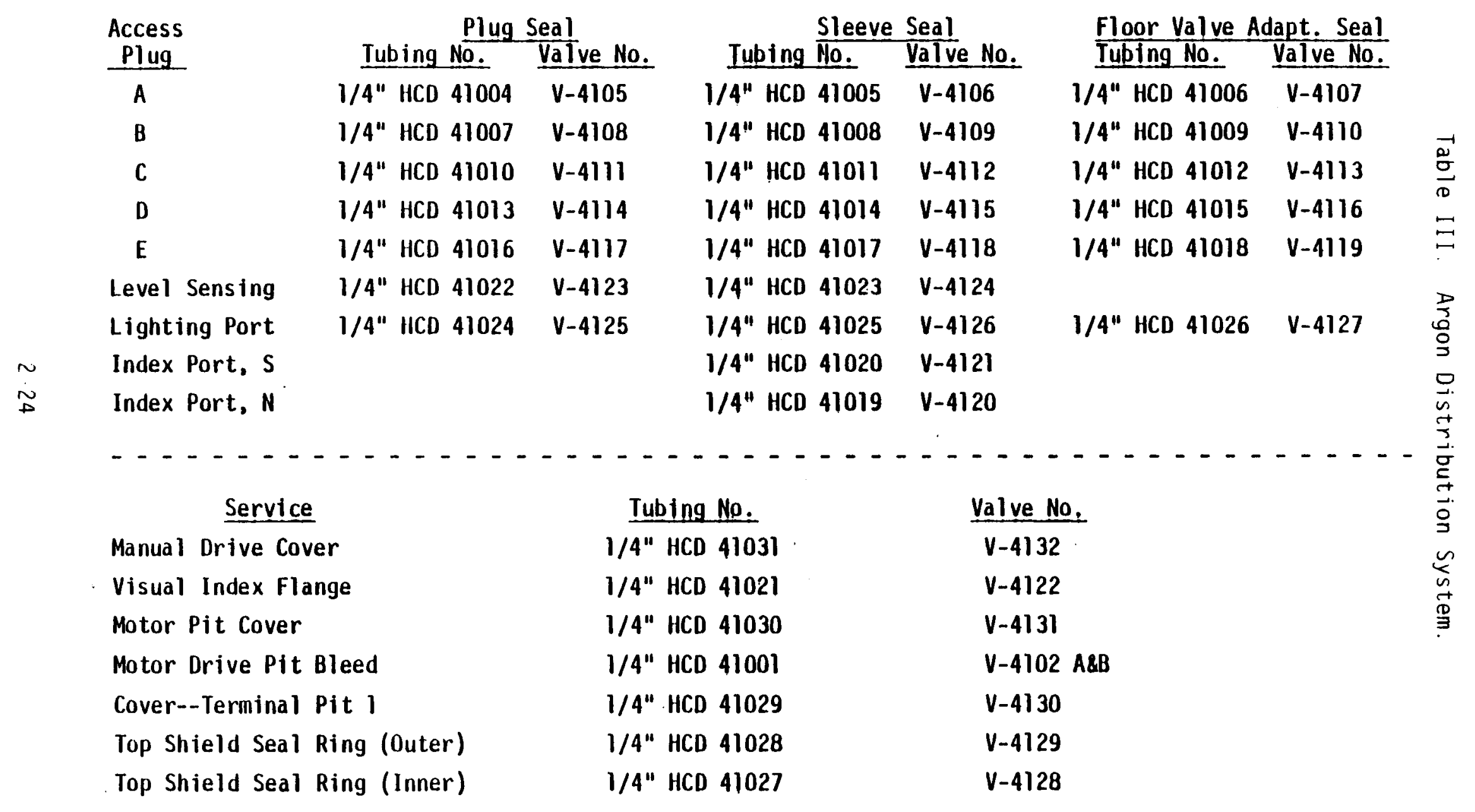


removable section over the vapor trap. There is a smaller rectangular removable section above the vault access opening on the northern end of the west side. The neutron shield between the BLTC rails is divided near the east-west centerline into two approximately equal-sized sections. The neutron absorber beneath and on either side of the IDS rails are special polyethylene shapes which are not steel jacketed. Polyethylene will also be inserted in the inside of the rail support crush tube for neutron absorption. The plugs for the various access ports which penetrate the impact absorber and the neutron absorber are designed to provide a polyethylene filled cavity to replace that removed for the access port.

The neutron absorber will also transmit the loads imposed by the eastern and western edges of the striker plate to the top shield or the support structure.

The neutrons are slowed to essentially thermal energy levels by the polyethylene and are captured to a small extent by the hydrogen of the polyethylene but predominantly by the iron which surrounds the polyethylene. The capture gamma rays are shielded by. the impact absorber and other surrounding materials.

\subsubsection{Miscellaneous Parts and Special Tools (H-4-34071, H-4-34075, H-4-34080)}

Four special tools and one miscellaneous part are required by the IDS other than special tools such as the maintenance enclosure which will be required for reactor maintenance. These are:

A. Storage Basket Position Encoder Tool--This tool is needed to remove and reinstall the basket position encoder. For details, see Drawing H-4-34071. 
B. Drive Train Removal Tool--This tool is needed to move the drive train from its operating position to the hoisting position when it is necessary to remove and replace the drive train. For details, see H-4-34075.

C. A tool is needed for the operation of the manual basket drive. This will be a standard $5 / 8$ inch hex socket with a standard speed wrench handle or a slow speed electric or air-powered wrench. Since this is a standard tool, it has not been provided.

D. $0 i 1$ Recovery Device--Should the lower seal on the drive train gear reducer fail, the oil will be caught in the special pan provided. Some sort of vacuum device will be required to extract this $0 i 1$ before the drive train is removed from its position. This special tool has not been provided.

One miscellaneous part is required for maintenance. This is an adapter to form a seal between the top shield and the maintenance enclosure or greenhouse used when removing or replacing a basket position encoder. This part has not been provided. See H-4-34080 for its design.

No tool has been provided nor has one been designed for the removal and replacement of a core component or test element storage tube. The IDS has been designed so that replacement is possible with the proper tools.

\subsubsection{Inter locks}

A semi-automatic basket positioning system has been provided for the IDS. Since it is possible to direct this mechanism to reposition the basket when severe damage would be the result, a system of interlocks has been provided to prevent such an occurrence. This system verifies automatically 
that all access plugs are in place or, if not, that the BLTC or CLEM Grapple is either in the fully retracted position or not at the port. If any of these conditions are met, it is safe to rotate the basket.

A second set of interlock circuits verifies that the IDS is in a safe condition to access. These interlocks require that the basket be stopped, that the basket position agrees with the address requested (except in the MANUAL mode), that the basket position produces an alignment between a storage location and an open port, and that the BLTC or CLEM is over the correct Floor Valve (manually entered by the operator). 


\subsection{SYSTEM LIMITATION, CASUALTY EVENTS, AND RESPONSE TO CASUALTY EVENTS}

\subsection{OPERATING LIMITS, SET POINTS, AND PRECAUTIONS}

\subsubsection{Operating Limits and Set Points}

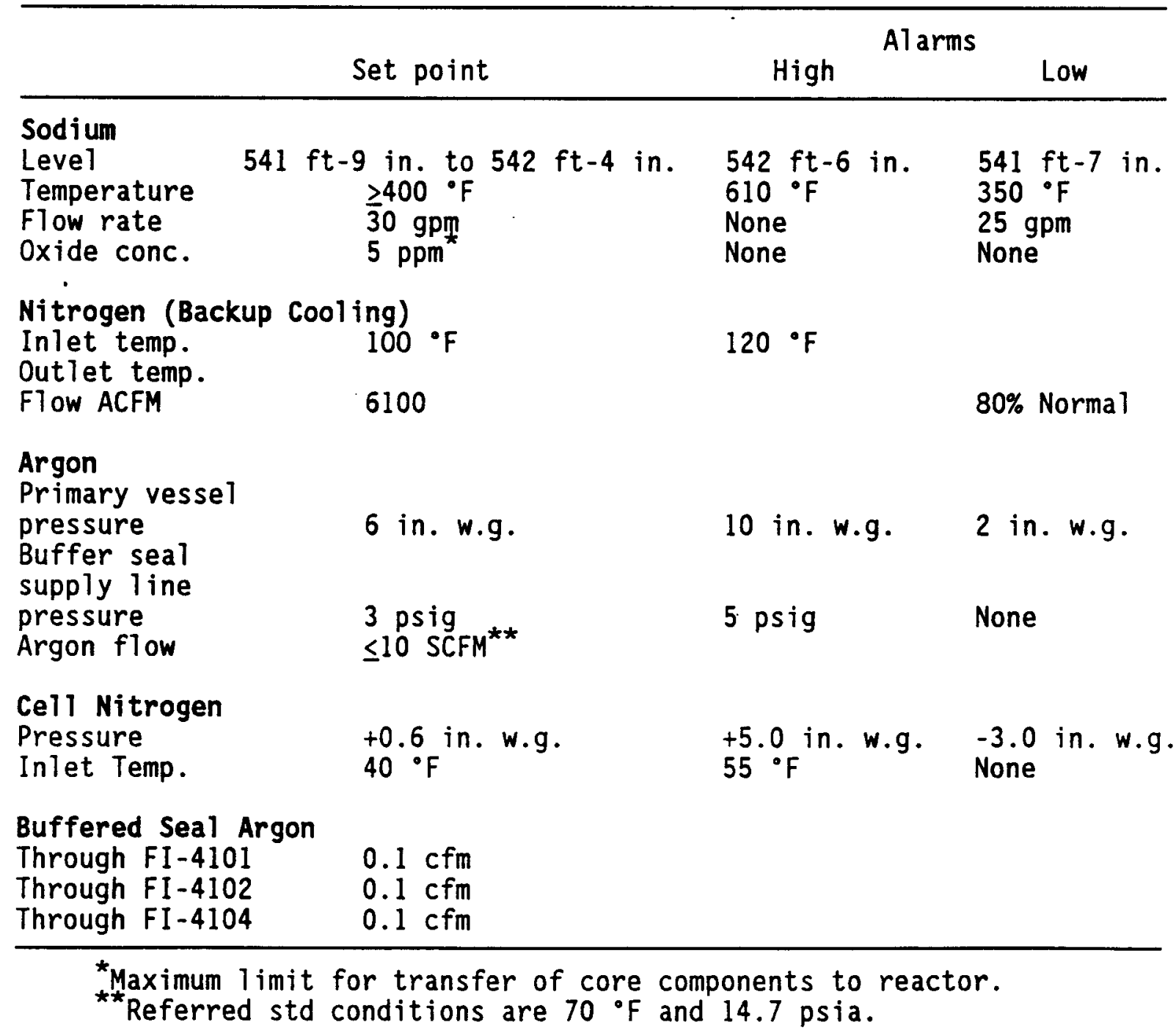




\subsubsection{Precautions}

Sodium temperature must always be maintained at least 50 ' $\mathrm{F}$ higher than the plugging temperature but never higher than $400^{\circ} \mathrm{F}$.

Argon flow rate to buffered seals should be low. Any significant change in argon flow to the buffered seals will indicate a leaking seal. The faulty seal should be identified and repaired.

A reduction in sodium flow rate from the IDS to the System 81 intermediate heat exchanger can result in inadequate cooling. Should the flow rate of sodium drop, preparation for the activation of the standby nitrogen system should be started.

\subsection{CASUALTY EVENTS}

The casualty events which can be experienced by the system are as follows:
A. Loss of primary cooling
B. Loss of electrical power
C. System leakage
D. Dropped load on IDS cover
E. Dropped core component during transfer
F. Dropped test assembly during transfer
G. Stuck core component during transfer
H. Loss of cover gas
I. Earthquake
J. Sodium fire
K. Cell overpressure
L. Vessel overpressure. 


\subsection{DESIGN FEATURES TO MITIGATE THE EFFECTS OF A CASUALTY EVENT}

\subsubsection{Loss of Primary Cooling}

Should the sodium circulation loop become inoperative either because of a component failure or for a maintenance procedure, the primary cooling system for the IDS will be inoperative. In this event, it will be necessary to activate the backup $\mathrm{N}_{2}$ cooling system. The backup $\mathrm{N}_{2}$ cooling system circulates nitrogen gas through a cooling annulus between the guard tank and the IDS thermal insulation. This system rejects heat to a refrigerated water/glycol system through a gas-to-oil heat exchanger. This stand-by system does not require the circulation of sodium to control IDS temperature within rormal operating limits.

\subsubsection{Loss of Electrical Power}

Should the electrical power supply to the FFTF be interrupted for any appreciable length of time, an emergency cooling system has been provided for the IDS and may be activated by manual operation of four block valves if containment is accessible. The IDS decay heat inventory is limited to $155 \mathrm{~kW}$.

\subsubsection{System Leakage}

A sodium level detector has been provided to monitor the sodium level in the primary vessel, and a guard tank has been placed around the primary vesse 1 to catch any sodium which leaks from the primary vessel. The guard tank will, in the event of a primary vessel failure, maintain the sodium level above the fueled portion of the core components and above the sodium circulation system suction inlet. The sodium circulation inlet is located high enough that, should a circulation fault occur, it would not be possible to pump the sodium level low enough to expose the fueled portion of 
the core components. A sodium detector has been placed in the guard tank to detect the presence of sodium in the guard tank. An antisiphon device has been provided to prevent siphoning of sodium from the primary vessel should the sodium circulation inlet line fail.

\subsubsection{Dropped Load on the IDS Cover}

The cover of the IDS has been designed to withstand the maximum possible dropped load without breaching the pressure boundary or impairing the access to any specific storage location within the facility. Hypothetical dropped loads, which the IDS is designed to withstand, are detailed in Paragraph 1.2.3.H of this document. Impact absorbing devices, which will stop dropped loads without damage to the top shield or access plugs, have been included in the design. The impact absorbing devices and the striker plate may be replaced readily without disturbing the pressure boundary or increasing the radiation exposure rate above the specified maximum for that location.

\subsubsection{Dropped Core Component During Transfer}

Core component storage tubes and core component pots have been designed so that no damage will occur to either should a core component storage pot with core component be dropped while in the process of insertion into the IDS. The clearance between the core component storage pot and the core component storage tube has been made such that the storage pot acts as a piston entering the storage tube, and the energy in the falling storage pot is dissipated as frictional pressure drop by the sodium as it is forced through the holes in the storage tube or between the pot and tube.

Should a core component be dropped while being inserted into or removed from a core component storage pot, which is in a core component storage tube, the tube will be seriously damaged. The stress imposed on the tube 
metal will be well into the plastic range. The anticipated elongation is not expected to be sufficient to cause failure of the metal. The tube will be damaged to the extent that it should not be used again. The damage will be confined to the tube.

\subsubsection{Dropped Test Assembly During Transfer}

Test assemblies will not be handled in storage pots so that a different approach is required to dissipate energy from a dropped test assembly. A special hydraulic piston arrangement is provided in the bottom of each test assembly storage tube. This device is capable of stopping a test assembly plug grapple which has been dropped from the highest elevation it may possibly reach without allowing the assembly to punch through the bottom of the storage tube.

\subsubsection{Stuck Core Component During Transfer}

Should a core component become immobilized for any reason while it is being loaded into the IDS, the heat dissipation capability of the floor valve, floor valve adapter, impact absorber, and transfer machine is great enough (even in a passive mode) to prevent the core component from being heated beyond an acceptable level. The analysis which demonstrates this is based on the assumption that: (1) the heat rejection rate for the component is $10 \mathrm{~kW},(2)$ it is stuck in the least favorable position seen during transfer, and (3) the condition exists until a thermal equilibrium is established with the surroundings. 


\subsubsection{Loss of Cover Gas}

A11 nonwelded pressure boundary closures are formed by double elastomeric seals which are buffered with argon gas so that any possible leakage will be from the buffered zone. Flow rates and pressure in these buffered zones are readily monitored. System 82 will furnish make-up argon as required.

\subsubsection{Earthquake}

The IDS and all its individual components are designed to withstand a Design Basis Earthquake without failure. This includes loads and seismic reactions when the floor valve and any of the mating equipment are in place.

\subsubsection{Sodium Reaction}

Argon atmospheres will be provided and maintained as an inert cover gas in all IDS facilities containing sodium. The sodium-filled vessel will be surrounded with an inert gas maintained in a cavity to minimize reactions with oxygen in the event of leaks.

Since storage facility sodium becomes mixed with reactor system cooling during transfers, low oxygen levels will be maintained to prevent subsequent oxide contamination of the reactor primary system sodium. All vessel access plugs and penetrations to areas containing air atmospheres will be provided with double seals to exclude oxygen. Floor valves, seals, and inerted cavities will maintain isolation and confinement during transfers. Sodium levels in the storage vessels will be maintained at proper levels to prevent overflow spills. The vessels will be designed for a high degree of integrity to minimize the possibility of failures and/or sodium leakage. The sodium circulating system and associated equipment will be arranged to prevent the possibility of inadvertent depletion of storage sodium. 


\subsubsection{Cell Overpressure}

The primary vessel has been designed to tolerate an external pressure 14.7 psi greater than the internal pressure. This condition can be achieved only by pressurizing the entire containment vessel. The seals on the IDS cell would not hold that differential between the cell and the operating area.

\subsubsection{Vessel Overpressure}

The primary vessel is designed to withstand a pressure of 4 psi above the static head of sodium at temperatures to $700^{\circ} \mathrm{F}$. Overpressure protection is provided by rupture discs which vent to the IDS cell. A pressure of 8.9 psi will $1 \mathrm{ift}$ the head.

\subsection{RECOVERY PROCEDURES}

\subsubsection{Loss of Primary Cooling}

Upon the loss of primary cooling, the precise cause must be determined. If a circulating pipe failure is the cause, the location of the failure must be discovered and a repair procedure initiated. If this is a system 81 failure, the recovery procedure is covered in SDD 81 . Should the primary cooling failure be caused by an increase in sodium impurities, the source of the contamination must be determined and repaired. Buffered seals will be a prime suspect in this event. Detection of the condition and decontamination of the sodium will be a System 81 function. 


\subsubsection{Loss of Electrical Power}

Electrical power is furnished IDS by System 12. Recovery procedures are discussed in SDD 12.

\subsubsection{System Leakage}

If a leakage occurs in the primary vessel, it will be necessary to: remove all stored core components and test assemblies to another storage facility, in-reactor storage, or a reprocessing facility; reclaim the sodium from the guard tank and the primary vessel; disassemble the facility; repair and replace the vessel; or install a new vessel.

Sodium circulation is provided by the auxiliary liquid metal system, and the responses to alarms and abnormal operating conditions in that system are provided in SDD 81 .

\subsubsection{Dropped Load on IDS Cover}

If a load is dropped on the top of the IDS and permanent deflection of one or more impact absorber tubes and/or the striker plate results, damaged components must be replaced before further operation of the IDS. Replacement of components above the top shield will not affect the safe operation of IDS.

\subsubsection{Dropped Core Component During Transfer}

Should a core component in a core component pot be dropped into a storage tube, no damage will result. Should a core component be dropped into an empty storage tube or into a storage pot which is in the storage tube, damage to the tube will result. That storage tube should not be used again. 


\subsubsection{Dropped Test Assembiy During Transfer}

Should a test assembly be dropped into a test assembly storage tube, the hydraulic energy absorber in the bottom of the tube will stop the assembly without damage to the tube or assembly. The energy absorber will automatically reposition after the incident.

The spring disengaged position of the test assembiy should be checked during removal of the test assembly to assure that the energy absorber is properly repositioned. This can be checked by observing the load on the CLEM grapple during the removal of the test assembiy. Any change in the spring disengaged position of the test assembly will indicate that the storage tube must be removed and replaced before it is used again.

\subsubsection{Stuck Core Component During Transfer}

A core component which is immobilized in mid-transfer will cause a temperature and radiation level excursion. Such an incident, should it persist, will damage the elastomeric portions of the buffered seals. Once an incident of this nature has occurred, the buffered seals on the floor valve, floor valve adapter, and the component-handling machine must be inspected or monitored closely to assure proper functioning. A damaged "0" ring would not seal properly and would allow excessive buffer gas leakage.

A study which estimated the equilibrium temperature of the fuel subassembly and the various parts of the IDS in an event of this nature was made. Even though a fuel subassembly emitting $10 \mathrm{~kW}$ of decay heat is immobilized in the most unfavorable position reached during the transfer operation, it is not anticipated that any of the metallic parts of the IDS or the transfer mechanism will exceed the design temperature, nor will the cladding on the fuel exceed the temperature limit for such an emergency. This study is reported in VITRO-R-193. 


\subsubsection{Loss of Cover Gas}

The loss of cover gas would result in a serious contamination of the IDS sodium. Should this occur, the cause of the gas loss must be located and repaired. The nature and extent of sodium contamination must be determined and a course of action be outlined. This procedure would involve purification by cold trap, or it could require the complete replacement of all the IDS sodium. Before the sodium could be replaced, all stored core components and test assemblies must be removed to safe storage.

\subsubsection{Earthquake}

In the event of an earthquake of the severity defined as a DBE, the IDS will survive and be capable of assisting in the safe shutdown of the reactor, including transfer of fuel. After the shutdown procedure is complete, the IDS may not be reactivated without a complete inspection of all components.

\subsubsection{Sodium Reaction}

A sodium-air reaction occurring within the primary vessel or the IDS cell is an unlikely event. If a number of events do occur, which should cause a sodium-air reaction within either the primary vessel or IDS cell, the event should be treated as a potentially faulted condition. The system may have to be deactivated, emptied, and inspected prior to the resumption of normal operation.

\subsubsection{Deleted}




\subsubsection{Cell Overpressure}

The amount of overpressure which the cell can sustain is not great enough to cause damage to any component of the IDS except as discussed in Paragraph 3.3.10, Sodium Fire. Should a pressure excursion occur, the oxygen content of the cell atmosphere should be monitored. An increase would indicate a leak, which should be located and sealed. Nitrogen makeup requirements should also be watched. An increase from normal would indicate a leak which should be located and sealed.

\subsubsection{Vessel Overpressure}

Any pressure excursion over 4 psi greater than cell pressure will result in the rupture of rupture discs in the argon system. Should this occur, rupture discs must be replaced.

\subsubsection{Sodium Piping Leakage}

Following a piping failure, the severity of the problem will establish the recovery methods. For the extreme case, the IDS must be unloaded of a11 inventory and sodium, and the cell and IDS rebuilt. 


\section{APPENDIX A}

\section{REFERENCES}

A. Seismic Design Criteria for the Fast Flux Test Facility Site, JABE-WADCO-02, Richland, Washington, dated June 1973.

B. FFTF Structure Response Curves for Seismic Design of FFTF Equipment, Specification HWS No. $1386($ G-6), Rev. 7, Bechtel Corp., June 6, 1973.

C. Safety Assurance Summary, HEDL-TME 71-150, Volume 1, dated (to be issued).

D. Letter, W. J. McShane to Director, FFTFPO, "IDS Emergency Cooling Deactivation," dated January 29, 1980, 7954595.

E. Letter, Director, FFTFPO, to W. J. McShane, "IDS Emergency Cool ing Deactivation," dated February 14, 1980, 8000174.

F. Letter, Director, FFTFPO, to W. J. McShane, "Transfer of ECS Cabling and Conduit to CMS," dated January 27, 1981, 8100206.

G. Memorandum, J. C. Guzek to G. R. Franz, "IDS Maximum Decay Heat Revised to $155 \mathrm{~kW}, " \mathrm{~T} / \mathrm{H}: 86-105$, June 9, 1986.

H. Memorandum, J. C. Guzek to T. H. Miles, "IDS Nitrogen Backup Cooling Hot Functional Tests and Recommended Operations," SD\&TA:81/181, December 22, 1981 .

I. Memorandum, J. C. Guzek to N. R. McFadden, "IDS Max Nominal Estimated Head Load With No Cooling," T/H:86/126, October 16, 1986. 


\section{APPENDIX B}

\section{TOP LEVEL DRAWINGS}

$\begin{array}{ll}\text { H-4-34002 } & \text { P\&I Flow Diagram--sodium System } \\ \text { H-4-34003 } & \text { P\&I Flow Diagram--gas Systems } \\ \text { H-4-34077 } & \text { IDS Primary Vessel and Guard Tank Arrangement--plan } \\ \text { H-4-34078 } & \text { IDS Primary Vessel and Guard Tank Arrangement--elevation } \\ \mathrm{H}-4-38001 & \text { IDS Assembly and Installation } \\ \mathrm{H}-4-38002 & \text { IDS Assembly and Installation Sections } \\ \mathrm{H}-4-38003 & \text { IDS Assembly and Installation Sections } \\ \mathrm{H}-4-38004 & \text { IDS Assembly and Installation Sections } \\ \mathrm{H}-4-38005 & \text { IDS Assembly and Installation Sections }\end{array}$


DD-41/5, Rev. 11 6-29-90

\section{APPENDIX C}

DATA SHEETS

C -1 


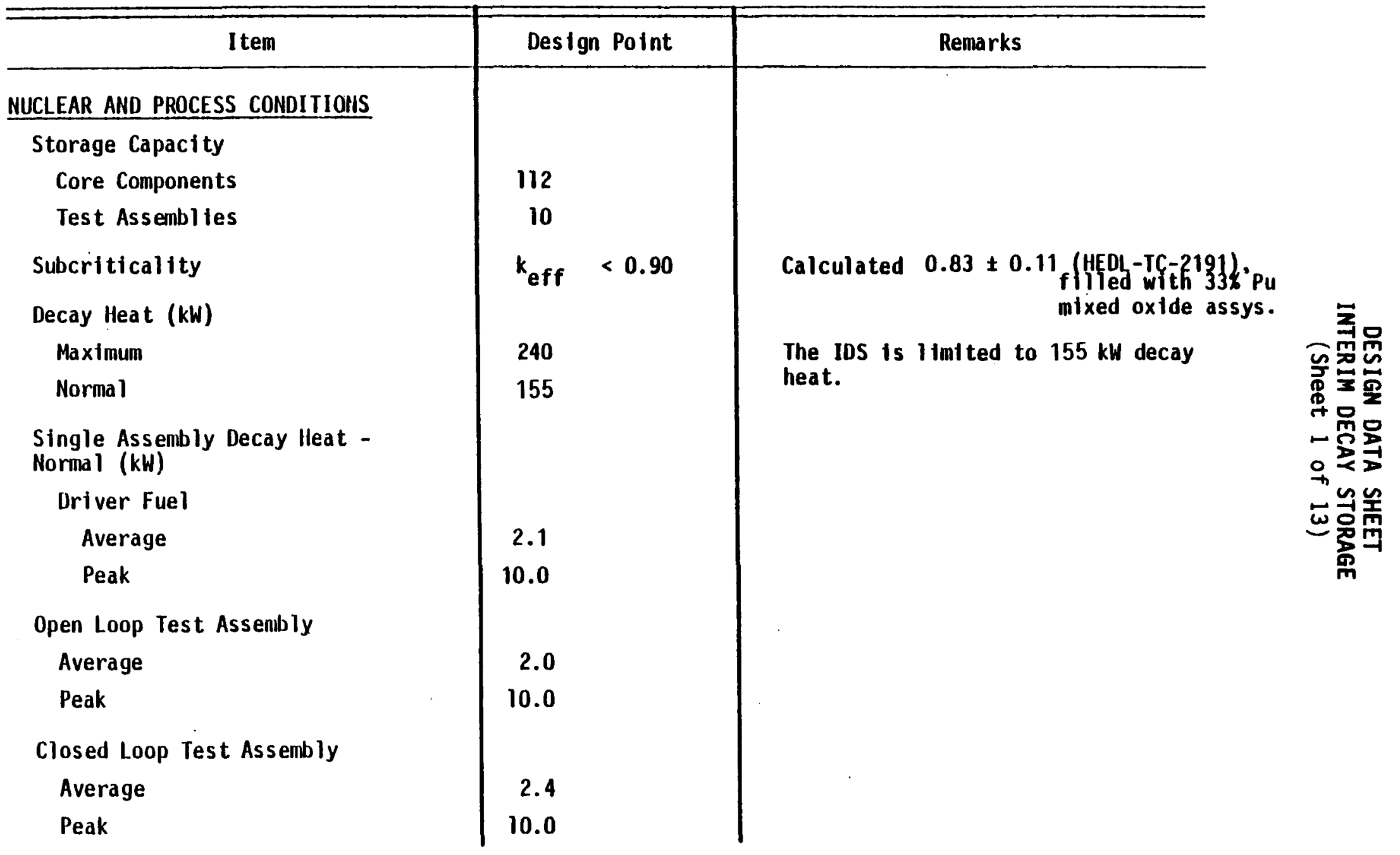




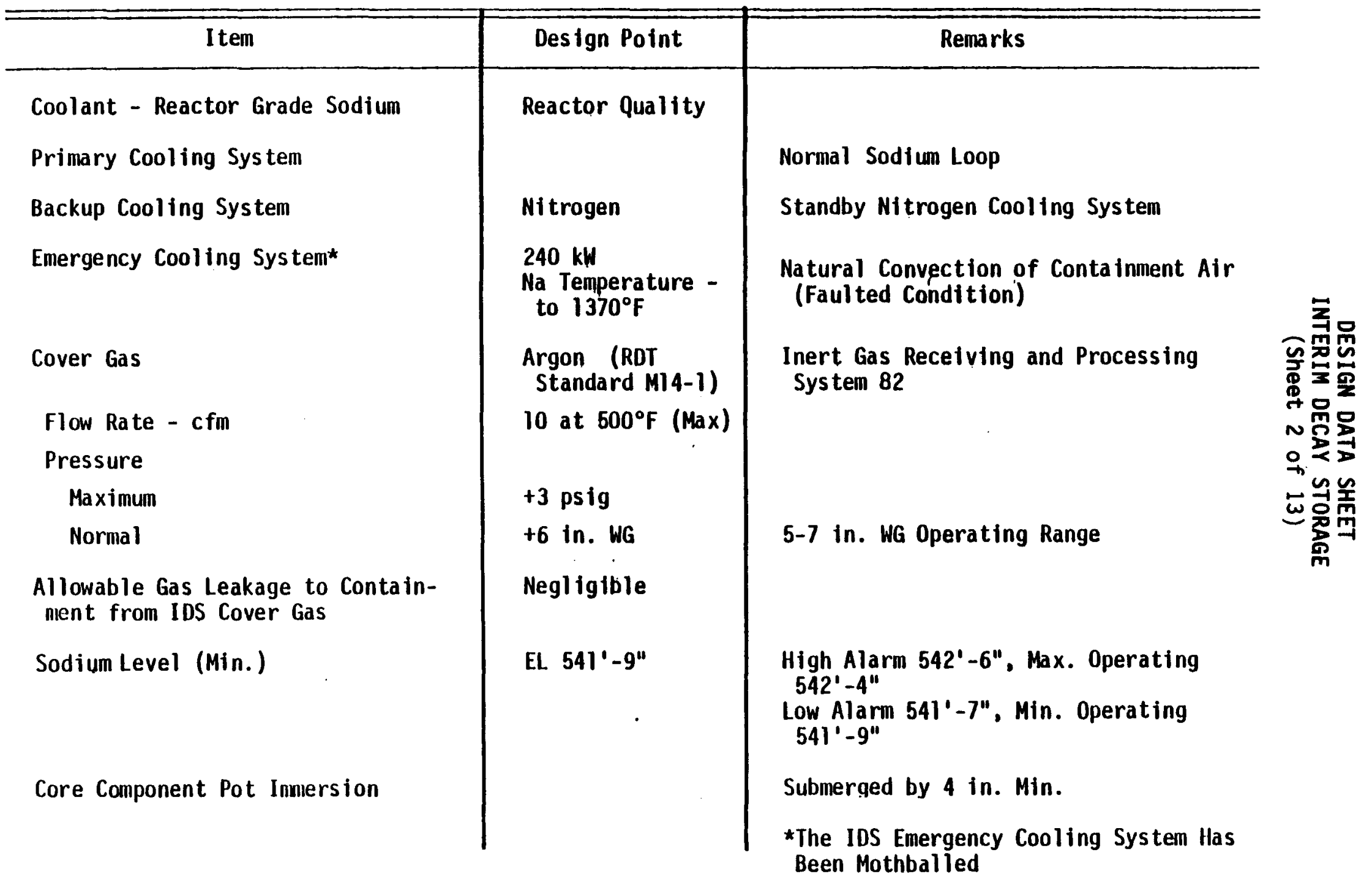




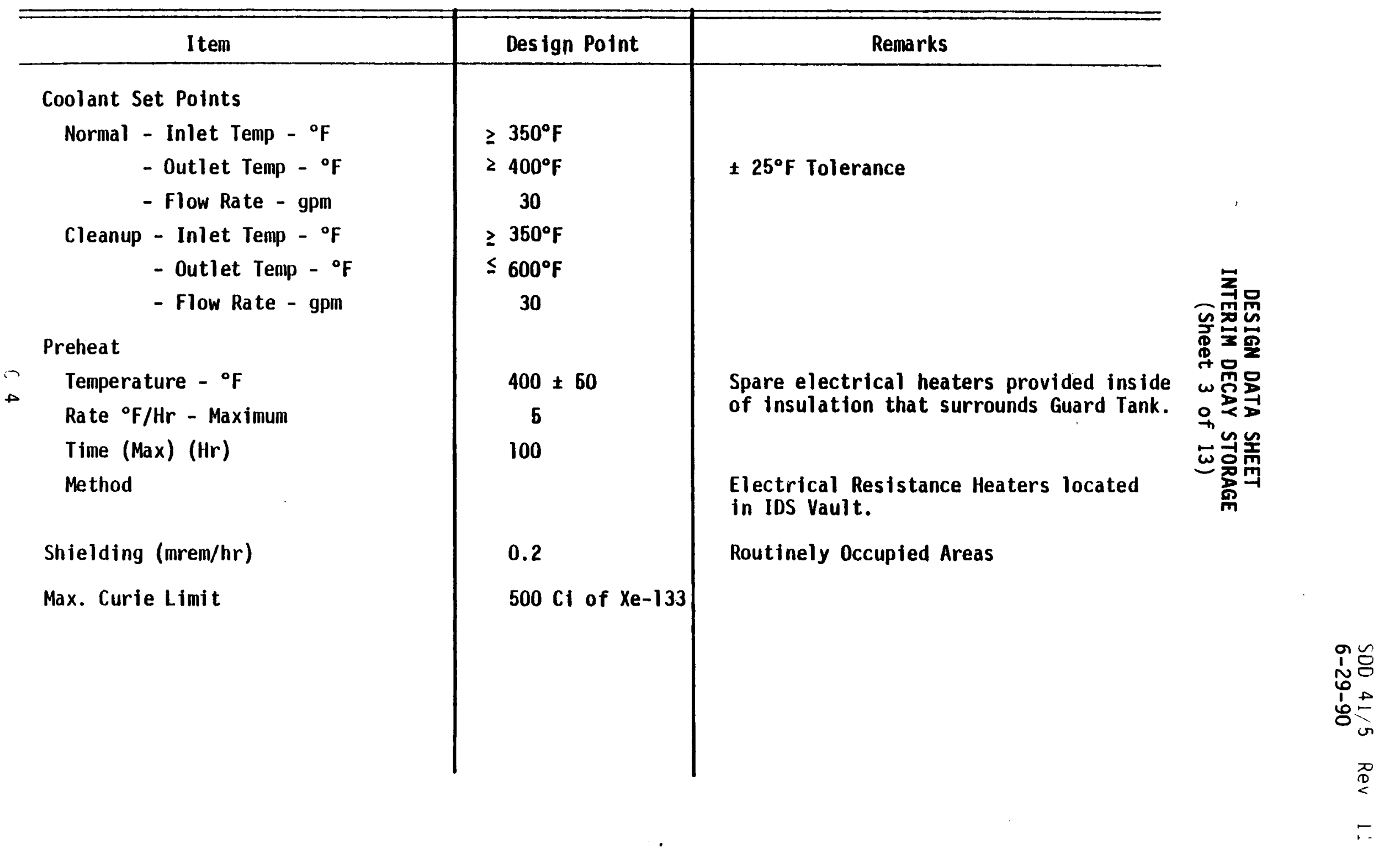




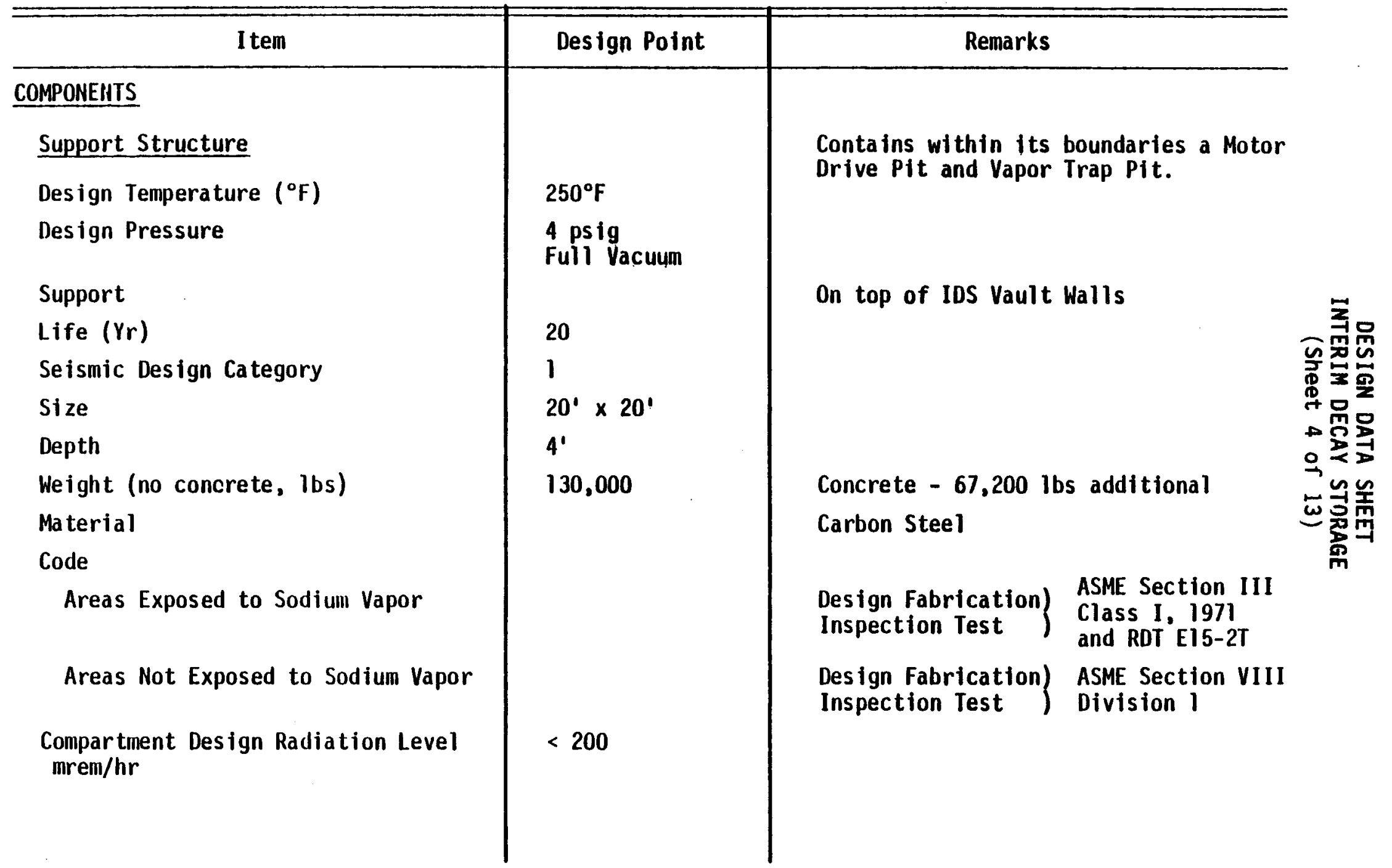




\begin{tabular}{|c|c|c|}
\hline Item . & Design Point & Remarks \\
\hline \multicolumn{3}{|l|}{ Primary Vessel } \\
\hline Material & & Type 304 StaInless Steel \\
\hline Code & & $\left.\begin{array}{l}\text { Design Fabrication } \\
\text { Inspection Test }\end{array}\right\} \begin{array}{l}\text { ASME Section III } \\
\text { Class } 1,1971 \\
\text { and RDT E15-2T }\end{array}$ \\
\hline Design Temperature $\left({ }^{\circ} \mathrm{F}\right)$ & 700 & \\
\hline Design Pressure at $700^{\circ} \mathrm{F}$ & $\begin{array}{l}4 \text { psi + Static } \\
\text { Head of } 41 \text { of } \\
\text { Full Vacuum }\end{array}$ & \\
\hline Support & & Hung from Top Ring Flange \\
\hline Life $(Y r)$ & 20 & \\
\hline Seismic Design Criteria & Category 1 & $\begin{array}{l}\text { JABE-WADCO-02, Nov 1970, and HWS-1386, } \\
\operatorname{Rev} 7\end{array}$ \\
\hline Outside Diameter (in.) & & \\
\hline Upper Flange & $176 \mathrm{in.}$ & \\
\hline Upper Shell & $150 \mathrm{in.}$ & \\
\hline Lower Shell & $61-1 / 8 \mathrm{in}$ & \\
\hline Nominal Thickness & $9 / 16$ in. & \\
\hline Overall Length & $44^{\prime} 9-1 / 2^{\prime \prime}$ & \\
\hline Weight (Lb) & 38,350 & Empty \\
\hline Inventory (Lb) & $127,000 \pm 1,000$ & Sodium at $400^{\circ} \mathrm{F}$ \\
\hline
\end{tabular}


DESIGN DATA SHEET

INTERIM DECAY STORAGE

\begin{tabular}{|c|c|c|c|}
\hline I tem & Design Point & Remarks & \\
\hline \multicolumn{4}{|l|}{ Guard Tank } \\
\hline Material & & Carbon Steel & \\
\hline Code & & $\begin{array}{l}\text { Design Fabrication) } \begin{array}{l}\text { ASME Section VIII } \\
\text { Inspection Test }\end{array} \text { Division 1, 1971 }\end{array}$ & \\
\hline Design Temperature $\left({ }^{\circ} \mathrm{F}\right)$ & 700 & & \\
\hline Design Pressure at $700^{\circ} \mathrm{F}$ & & Static Head of Sodium & 足 \\
\hline Support & & $\begin{array}{l}\text { Flanged Pedestal at Lower End of Upper } \\
\text { Section }\end{array}$ & 栾员 \\
\hline Life $(\mathrm{Yr})$ & 20 & & $0 \geqslant$ \\
\hline Seismic Design Criteria & Category 1 & JABE-WADC0-02, Nov 1970; HWS-1386, Rev 7 & 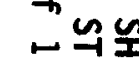 \\
\hline Size Criteria & & $\begin{array}{l}\text { Annular Volume Between Guard Tank and } \\
\text { Primary Vessel to Limit Leakage of Sodium } \\
\text { from Primary Vessel to Prevent Uncovering } \\
\text { the Active Fuel Section of the Driver Fuel } \\
\text { and Test Assemblies }\end{array}$ & 当号商 \\
\hline $\begin{array}{l}\text { Insulation Outside Temp } \\
(\operatorname{Max})\left({ }^{\circ} \mathrm{F}\right)\end{array}$ & 140 & $\begin{array}{l}\text { Insulation to be Spaced 6" Radially from } \\
\text { Guard Tank and Support from Cell Wall }\end{array}$ & \\
\hline Upper Shell (00 in.) & 155 & Volume of Guard Tank Shall be Such that & \\
\hline Lower Shell (00 in.) & & $\begin{array}{l}\text { the Content of the Primary Vessel at the } \\
\text { Minimum Level will be sufficient to cover }\end{array}$ & \\
\hline Nominal Thickness & $1 / 2$ inch & $\begin{array}{l}\text { the Active Fuel Section of the Driver Fuel } \\
\text { Assemblies }\end{array}$ & \\
\hline Overall Length $(F t)$ & $40^{\prime}-5^{\prime \prime}$ & & \\
\hline Weight (Lb) & 24,300 & & \\
\hline
\end{tabular}


DESIGN DATA SHEET

INTERIM DECAY STORAGE

\begin{tabular}{|c|c|c|}
\hline Item & Design Point & Remarks \\
\hline \multicolumn{3}{|l|}{ Top Shield Assembly } \\
\hline \multicolumn{3}{|l|}{ Material } \\
\hline Structural & & Carbon Steel \\
\hline Insulation & & $\begin{array}{l}\text { Reflective } 304 \text { Stainless Steel Sheets } \\
\text { Spaced Approximately 0.6" Apart }\end{array}$ \\
\hline $\begin{array}{l}\text { Code - Confinement Boundary Only } \\
\text { Other Section VIII Div. } 1 \\
\text { ASME Materials }\end{array}$ & & $\left.\begin{array}{l}\text { Design Fabrication } \\
\text { Inspection Test }\end{array}\right\} \begin{array}{l}\text { ASME Section III } \\
\text { Class 1, 1971 } \\
\text { and RDT E15-2T }\end{array}$ \\
\hline \multicolumn{3}{|l|}{ Design Temperature $\left({ }^{\circ} \mathrm{F}\right)$} \\
\hline Bottom & $120^{\circ} \mathrm{F}$ & \\
\hline Top (550' Level) & $100^{\circ} \mathrm{F}$ & \\
\hline Support & & $\begin{array}{l}\text { On IDS Support Structure at Top of IDS } \\
\text { Vauit }\end{array}$ \\
\hline Life $(Y r)$ & 20 & \\
\hline Seismic Design Criteria & Category 1 & JABE-WADC0-02, Nov 1970; HWS-1386, Rev 7 \\
\hline Transfer Ports & 5 & $\begin{array}{l}\text { One Per Storage Circle } \\
10-3 / 4^{\prime \prime} \text { Diameter Stepped Plugs }\end{array}$ \\
\hline Instrumentation and Access Ports & 4 & \\
\hline 入 & & \\
\hline
\end{tabular}


DESIGN DATA SHEET

INTERIM DECAY STORAGE

\begin{tabular}{|c|c|c|}
\hline Item & Design Point & Remarks \\
\hline \multicolumn{3}{|l|}{ Railroad Track } \\
\hline Standard Guage $\left(4^{\prime}-8-1 / 2^{\prime \prime}\right)$ & & $\begin{array}{l}\text { Railroad Track to be Installed on Top } \\
\text { Shleld. Centerline of track to be } \\
\text { coincident with centerline through row } \\
\text { of fuel ports. }\end{array}$ \\
\hline \multicolumn{3}{|l|}{ Loads on Track (Ton) } \\
\hline BLTC and Transporter & 85 & \\
\hline Segmented Cask and Railroad Car & 192 & \\
\hline Railroad Car & & $\begin{array}{l}\text { Two trucks with centerline spacing of } \\
45^{\circ} \text {. Each truck has four axles with } C_{L} \\
\text { spacing of } 5^{\circ}-6^{\prime \prime} \text {. }\end{array}$ \\
\hline Vehicle Speed on IDS & $5 \mathrm{ft} / \min (\max )$ & \\
\hline \multicolumn{3}{|l|}{ Impact Absorber } \\
\hline Size & $20 \mathrm{ft} \times 20 \mathrm{ft}$ & \\
\hline Location & & Set on Top Shield and Support Structure. \\
\hline \multicolumn{3}{|l|}{ Dropped Loads } \\
\hline Floor Valve & & 8.5 tons from $24^{\prime \prime}$ height, with edge impac \\
\hline Segmented Maintenance Cask & & $\begin{array}{l}142 \text { tons from } 33^{\prime \prime} \text { height, onto one side of } \\
\text { railiroad car, such that the major load is } \\
\text { taken by four wheels of the truck located } \\
\text { over IDS Cover. }\end{array}$ \\
\hline Design & & $\begin{array}{l}4^{\prime \prime} \text { thick steel striker plate, set on } 8 " \\
\text { dia and } 12^{\prime \prime} \text { dia thick crushable tubes, } \\
\text { load horizontally on a 4" (min.) sheet } \\
\text { of polyethylene encased in steel plate. }\end{array}$ \\
\hline
\end{tabular}




\begin{tabular}{c|c|c}
\hline Item & Design Point & Remarks \\
\hline
\end{tabular}

For preceding criteria, the IDS covers shall be repairable or replaceable. Internals and drives shall rema in operable.

Primary vessel and guard tank shall remain intact.

Pipe nozzles shall not rupture.

Storage items and sodium can be removed.

\section{Storage Basket Assembly} Speed of Rotation (Max) ( $r p m)$ Concentric Storage Rows Capacity of Storage Rows Storage Row E

Storage Row D

Storage Row C

Storage Row B
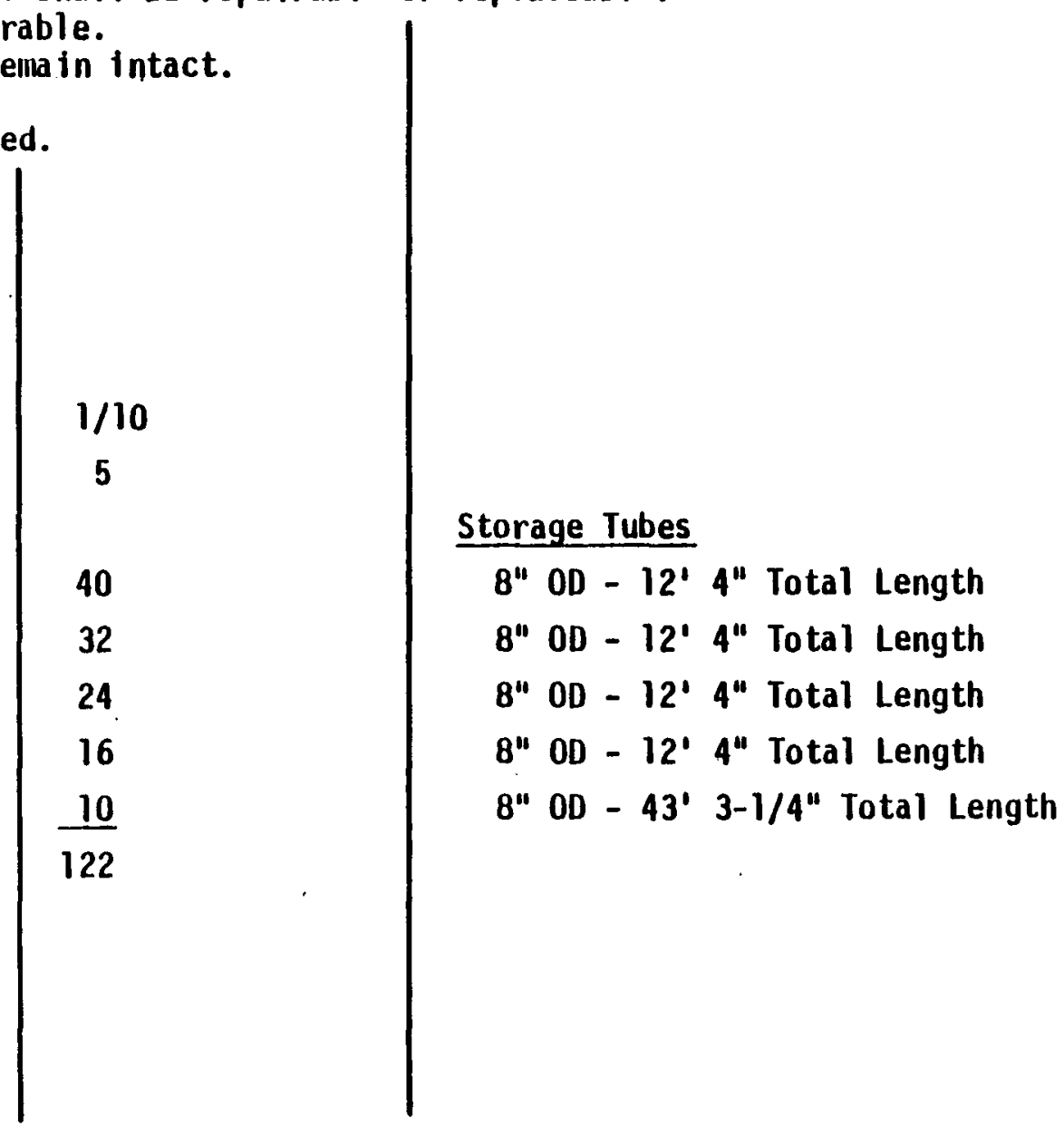
TOTAL.

$$
\begin{aligned}
& \text { 8" OD - 12' 4" Total Length } \\
& \text { 8" OD - 12' 4" Total Length } \\
& \text { - } 12^{\prime} 4^{\prime \prime} \text { Total Length } \\
& \text { OD - 12' 4" Total Length }
\end{aligned}
$$$$
\text { Storage Row A (Test Assy's) }
$$$$
\text { TOTAL }
$$ 


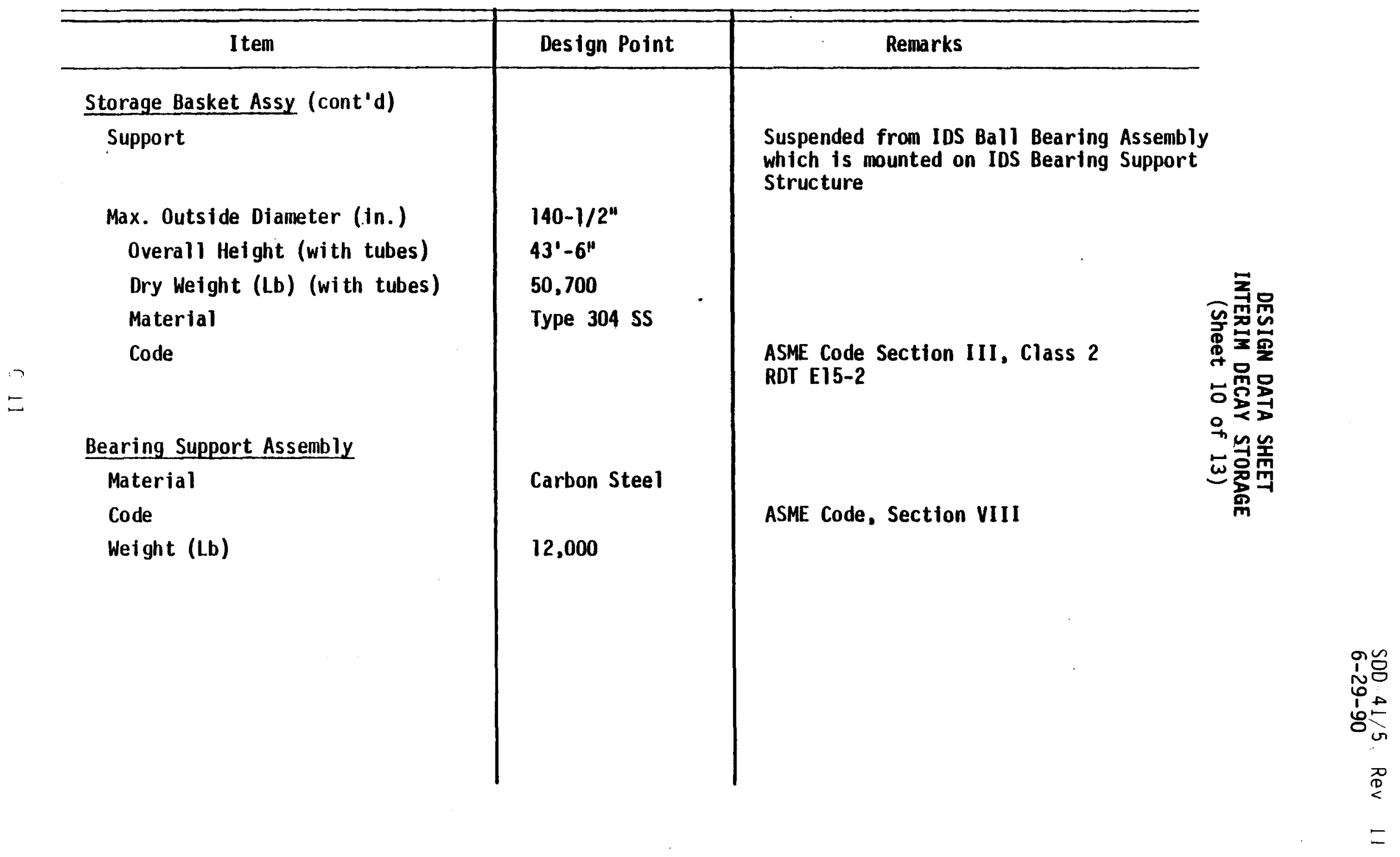




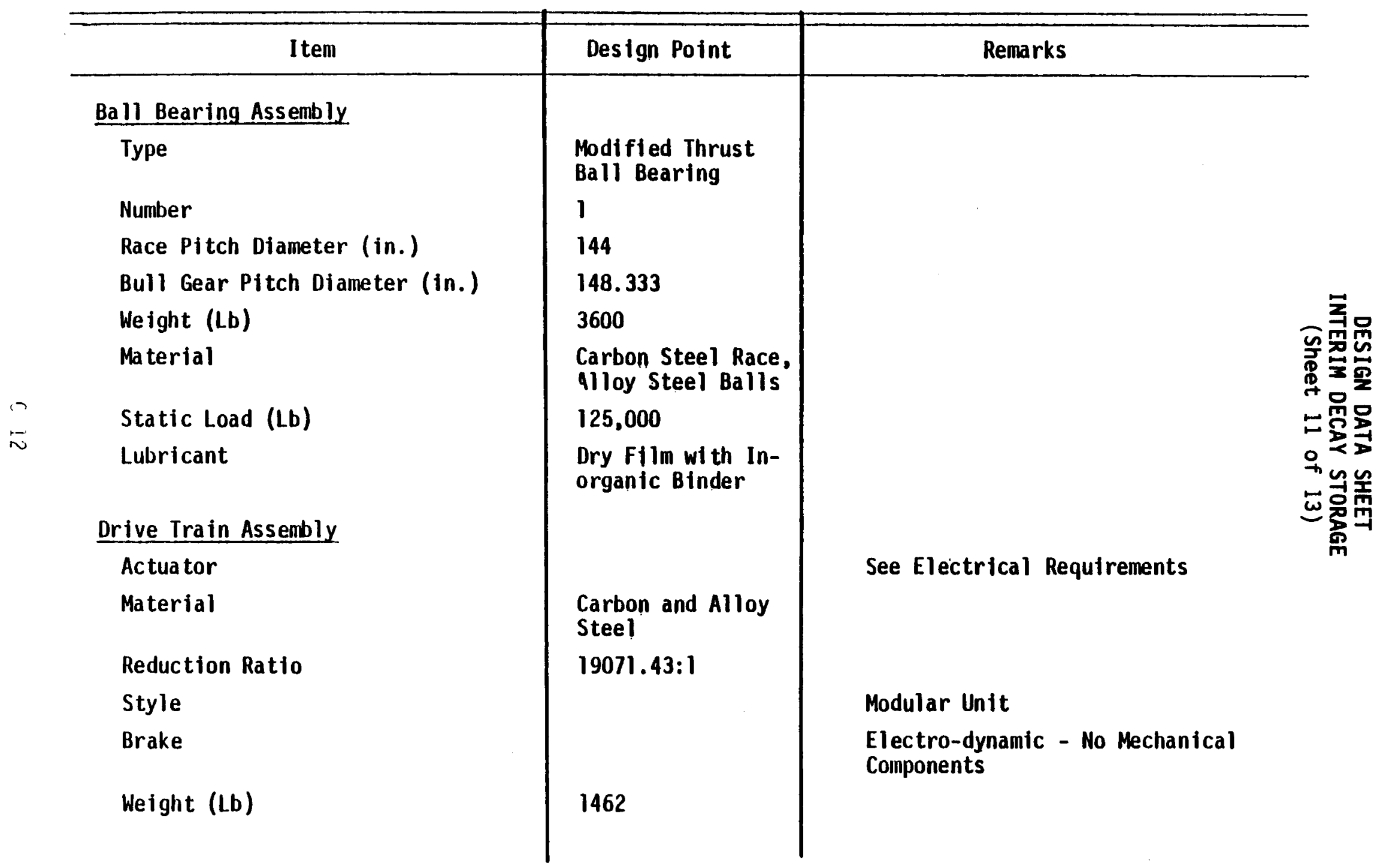




\begin{tabular}{|c|c|c|c|}
\hline Item & Design Point & Remarks & \\
\hline \multicolumn{4}{|l|}{ Storage Basket Indexing Assembly } \\
\hline \multicolumn{4}{|l|}{ Encoder } \\
\hline Power Requirements & 1 watt max. & & \\
\hline Type & Absolute Magnetic & & \\
\hline Total Count & 8192 & & \\
\hline Encoder/Storage Basket Drive Ratio & $64: 1$ & & \\
\hline $\begin{array}{l}\text { Style } \\
\text { ELECTRICAL REQUIREMENTS }\end{array}$ & & Modular Unit - Electro Mechanical & 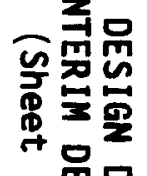 \\
\hline Drive Motor & $1.5 \mathrm{HP}$ & $\begin{array}{l}480 / 240 \text { volt, dual voltage, } 30 \text {, squirrell } \\
\text { cage induction, reversing. Class "H" }\end{array}$ & 战是是 \\
\hline Connectors/Receptacles & & $\begin{array}{l}\text { selected for IDS use because of argon } \\
\text { atmosphere in the drive }\end{array}$ & 光邑蔏 \\
\hline Thru-Bulkhead & For 3/4" Bulkhead & $\begin{array}{l}\text { Hermetically sealed, temperature and } \\
\text { radiation rated. Available with pins } \\
\text { for ISA Type } K \text { thermocouple applications. }\end{array}$ & 高每 \\
\hline Connector Socket & Cable Type & & \\
\hline Connector Pin & Cable Type & & \\
\hline Wire/Cable & & $\begin{array}{l}\text { Temperature and radiation rated where } \\
\text { required. }\end{array}$ & \\
\hline Thermocouple Lead Wire & Multi-wire Cable & & \\
\hline
\end{tabular}




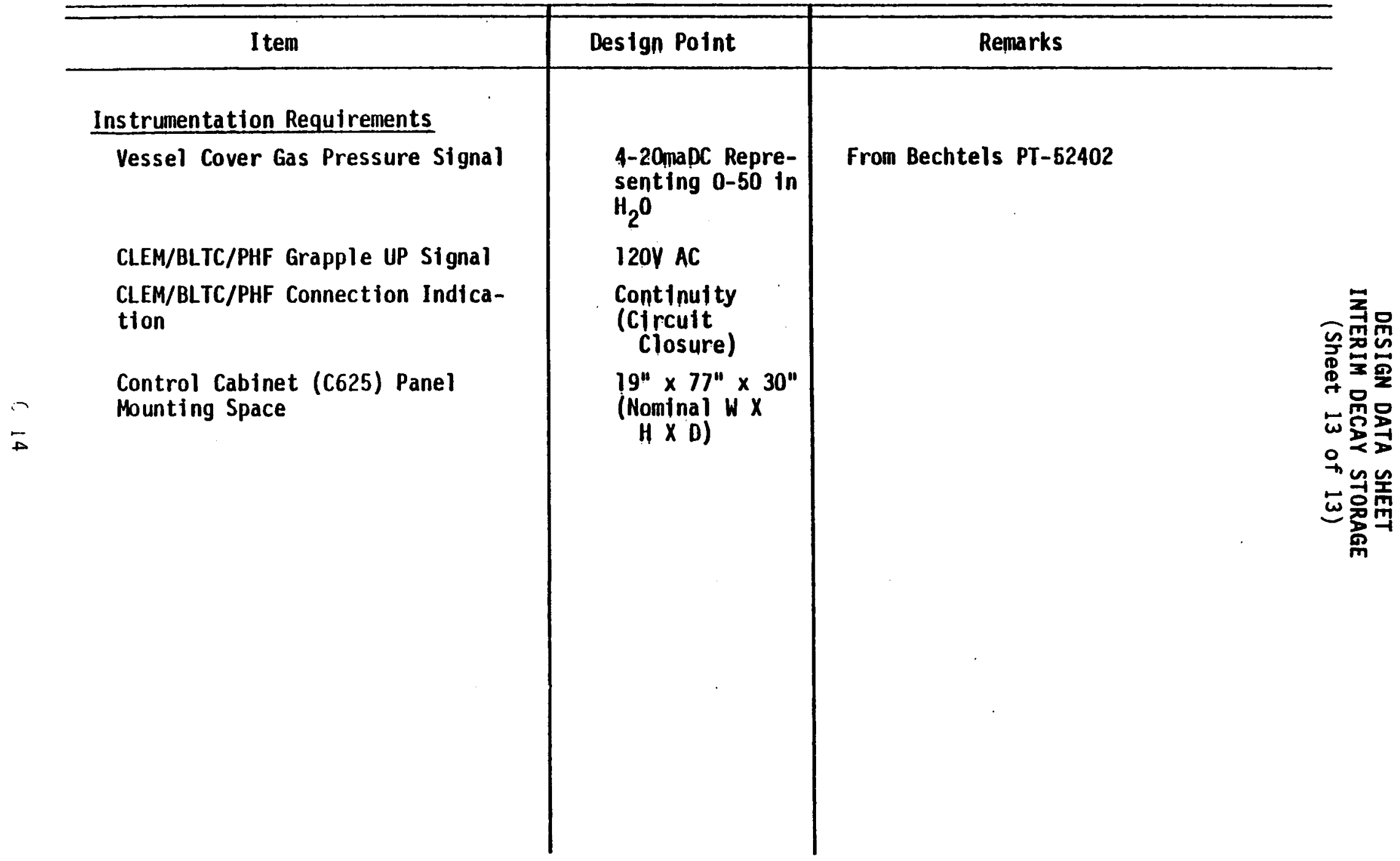

